\title{
PAWEL JASIENICA VERSUS JÓZEF MACKIEWICZ. CZYJA DROGA DONIKĄD?
}

\author{
Arkadiusz KIERYS (Toruń)
}

Wolność bez możliwości wyboru nie jest w ogóle żadną wolnością; człowiek musi przyjąć swoją kondycję i stale wybierać na własne ryzyko, nawet jeżeli karą jest śmierć.

Czesław Miłosz, Historia literatury polskiej

Biografie obu wilnian były podobne, wybory życiowe i światopogląd zbliżone, a spojrzenie na tradycję Wielkiego Księstwa Litewskiego wręcz identyczne. Wszystko zmienił wybuch drugiej wojny światowej i potrójna okupacja Wileńszczyzny, wówczas każdy poszedł własną drogą, która nie była wymarzoną drogą dla żadnego z nich.

Kwestia polemiki między Jasienicą a Mackiewiczem pojawiła się u autora niniejszego artykułu wraz z rozwojem pracy nad biografią Leona Lecha Beynara ${ }^{1}$; zgromadzony materiał pozwolił na własną refleksję nad tym bratobójczym pojedynkiem, w którym meritum przestało z czasem odgrywać jakąkolwiek rolę, a inicjatywę przejęli adwersarze obu stron, okopani i bezpieczni na swoich pozycjach. Przyznaję — artykuł jest formą obrony Jasienicy oskarżanego o współpracę z propagandą komunistyczną przeciwko Józefowi Mackiewczowi. Uważam, że nie tylko nigdy takiej współpracy nie było, ale i sam niezaprzeczalny atak dotyczył wyłącznie wewnętrznych kwestii kresowiaków - a nie polityki w wymiarze ideologicznym. Przyznaję rację Czesławowi Miłoszowi - wilnianinowi — który może właśnie z racji pochodzenia, cenił i szanował obu pobratymców, rozumiejąc zarazem ich dylematy.

Józef Mackiewicz doczekał się dwóch monografii ${ }^{2}$, jednej antologii ${ }^{3}$ i osobnego -

\footnotetext{
${ }^{1}$ A. Kierys, „Paweł Jasienica. Biografia publicysty w PRL-u” (w przygotowaniu).

${ }^{2}$ W. Bolecki, Ptasznik z Wilna. O Józefie Mackiewiczu. (Zarys monograficzny), Kraków 2007; G. Eberhardt, Pisarz dla dorostych. Opowieść o Józefie Mackiewiczu, Wrocław 2008.

${ }^{3}$ Józef Mackiewicz i krytycy. Antologia tekstów, pod red. M. Zybury, Łomianki 2009.
} 
poświęconego jemu - tomu „Archiwum Emigracji”, dorobkiem nader obszernym. Beynar nie doczekał się biografii w pełnym tego słowa znaczeniu - powstały dwie prace przypominające zarys monograficzny — pierwsza, to praca magisterska Bernarda Wiadernego ${ }^{5}$, ograniczona zakresem chronologicznym do lat wojny i okupacji, i - co zrozumiałe - pozbawiona źródeł archiwalnych MSW, dziś spoczywających w Instytucie Pamięci Narodowej. Druga, to wspomnienia córki Pawła Jasienicy, Ewy Beynar-Czeczott ${ }^{6}$, mające - siłą rzeczy — charakter pamiętnikarski. Jasienica pozostawił także niedokończony Pamiętnik pisany pod koniec życia ${ }^{7}$.

Najlepiej jednak mówią o sobie sami zainteresowani w swych dziełach, których podobnie jak w wypadku szkiców i artykułów przyjaciół i kolegów po piórze — nie sposób tutaj, ze względu na ograniczoność pracy, przytoczyć. Wymieniam je w przypisach.

\section{Gente Ruthenus}

Różnica wieku była niewielka — Józef urodził się w roku 1902 w Petersburgu, Leon siedem lat później w Symbirsku nad Wołgą — późniejszym Uljanowsku; obaj pochodzili z carskiej Rosji, dla obu pierwszym monarchą był Mikołaj II. Józef uczęszczał do gimnazjów w Wilnie i, nie zdawszy matury w terminie, jako ochotnik, zaciągnął się do ułanów, by walczyć z bolszewikami w wojnie roku $1920^{8}$. W tym czasie rodzina Beynarów uciekała z Ukrainy przed wojskami Budionnego i Tuchaczewskiego, bitwę warszawską przeżyli w „oblężonej” stolicy, ale szkołę gimnazjalną młody Lech ukończył już w Grodnie - do Wilna przybył na studia w 1928 roku. Ten pierwszy okres doświadczeń dziejowych wywarł podobny wpływ na obu chłopców. Zachowała się w ich świadomości nostalgia do mieszkańców ogromnego kraju lat dzieciństwa. Mackiewicz pisał o niezwykłej gościnności i przyjacielskich stosunkach z rosyjskimi rówieśnikami, mimo doby „niewoli i ucisku”, i podpisałby się zapewne także pod słowami Jasienicy, który w Pamiętniku przyznawał, że wywiózł na zachód dorobek w postaci szczerej sympatii do narodu rosyjskiego — wśród którego żył „nigdy nie kryjąc narodowości ani wyznania" $"$.

Studia rozpoczął Mackiewicz na Uniwersytecie Warszawskim na Wydziale Filozoficznym, gdzie zgłębiał nauki przyrodnicze — prawdziwą pasją była ornitologia. Przerwał je w stolicy i kontynuował krótko w Wilnie na Uniwersytecie Stefana Batorego (USB). Ale i te studia nie trwały długo, zaledwie rok, po czym zaczął robić coś, co, jak mu się wydawało, robi najlepiej - pisać. Pisał do „Słowa”, konserwatywnej gazety, w której redaktorem naczelnym był jego starszy brat, Stanisław Mackiewicz (w przyszłości znany jako Cat-Mackiewicz). Zasłynął reportażami, a ich zbiór wydany w tomie

${ }^{4}$ Archiwum Emigracji. Studia - Szkice - Dokumenty 2003 z. 5/6: blok artykułów zatytułowany „Józef Mackiewicz — szkice i wspomnienia” (s. 155-315).

5 B. Wiaderny, Pawet Jasienica. Fragment biografii, wrzesień 1939 - brygada Łupaszki 1945, Komorów 1991.

${ }^{6}$ E. Beynar-Czeczott, Mój ojciec Pawet Jasienica, Warszawa 2006.

${ }^{7}$ P. Jasienica, Pamiętnik, Warszawa 2007.

${ }^{8}$ W. Bolecki, Ptasznik z Wilna, s. 54-58.

${ }^{9}$ Tamże, s. 66, 116; ,Żaden chyba z pisarzy, a na pewno: pisarzy polskich nie żegnał carskiej Rosji z takim serdecznym żalem, w słowach tak strzeliście natchnionych, jak uczynił to autor Lewej wolnej”; W. Lewandowski, Rosja Józefa Mackiewicza, [w:] Józef Mackiewicz i krytycy, s. 551.

${ }^{10}$ P. Jasienica, Pamiętnik, s. 47-48. 
Bunt rojstów z 1938 roku, był prawdziwą rewelacją wydawniczą na Wileńszczyźnie ${ }^{11}$. Sam Ksawery Pruszyński pisał wówczas w recenzji:

Tragiczna, lecz państwowotwórcza, bo walcząca z zakłamaniem, łatwizną, kwietyzmem, jest książka Józefa Mackiewicza. Tyle książek czczych i głupich wydaje się dziś w Polsce, a tak kapitalne studium nie znalazło wydawcy! Będzie zwalczana, będzie przemilczana, zmobilizuje się przeciw niej ludzi o znanych nazwiskach [...]. Bo żadna nie miała bezczelności powiedzieć aż tak dużo prawdy. Tego nie zwykliśmy wybaczać ${ }^{12}$.

Proroctwo Pruszyńskiego spełniło się, życie i działalność Mackiewicza będzie ciągłym płynięciem pod prąd. Beynar zapamiętał go z tego okresu jako jednego z najlepszych polskich reportażystów, a przede wszystkim właśnie jako autora doskonałego Buntu rojstów $w^{13}$.

Studiując w latach 1928-1932 na USB, Jasienica uzyskał dyplom magistra filozofii

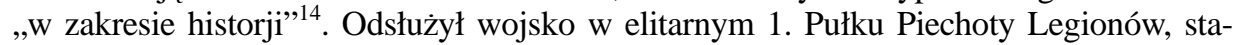
cjonującym w Wilnie, i po roku egzystencji ,przy rodzicach” — na bezrobociu — podjął pracę nauczyciela historii $w$ trzech gimnazjach: jednym państwowym, jednym prywatnym i jednym żydowskim ${ }^{15}$. Po dwóch latach wygrał konkurs na spikera Rozgłośni Polskiego Radia w Wilnie, gdzie spotkał przyjaciela z czasów studenckich - Czesława Miłosza $^{16}$. Jeszcze przed wojną wydał dwie prace: Zygmunt August na ziemiach dawnego Wielkiego Księstwa Litewskiego oraz Ziemie pótnocno-wschodnie Rzeczypospolitej Polskiej za Sasów, mające charakter pomocy dydaktycznej dla nauczycieli gimnazjum ${ }^{17}$.

Światopogląd obu wilnian ukształtował się w okresie dojrzewania, nauki i wkraczania w dorosłe życie. Dla Mackiewicza i Beynara podstawową wartością był liberalizm, czyli wolność jednostki ponad wszystko, natomiast największym grzechem ówczesnych społeczeństw była, według nich, ideologia nacjonalizmu ${ }^{18}$. Dla Józefa, ważnym problemem, będącym efektem postanowień traktatu wersalskiego, było istnienie państw wielonarodowych o charakterze nacjonalistycznym. W sensie geopolitycznym natomiast problem dotyczył dwóch potężnych podmiotów międzynarodowych — Niemiec i Rosji sowieckiej — które nie tylko nie akceptowały ładu wersalskiego, ale oficjalnie dążyły do jego obalenia $^{19}$. Szczególny niepokój budził jednak bolszewizm (zza wschodniej granicy), którego

11 „Mackiewicz opisywał geograficzną, społeczną i historyczną specyfikę ziem byłego Wielkiego Księstwa Litewskiego. Odkrywał i objaśniał nie rozpoznane wcześniej zjawiska i konflikty, zwłaszcza religijne i ekonomiczne, rozwijające się na tych terenach, odkąd stały się częścią II Rzeczypospolitej”; W. Bolecki, Ptasznik z Wilna, s. 146.

${ }^{12}$ K. Pruszyński, Książa o człowieku głębinowym, Wiadomości Literackie 1938 nr 9; cyt. za: Józef Mackiewicz i krytycy, s. 44.

${ }^{13}$ P. Jasienica, Moralne zwłoki szlachcica kresowego, Świat $1955 \mathrm{nr} 43$; przedruk w: tenże, Ślady potyczek, Warszawa 2009, s. 195.

${ }^{14}$ Fotokopia Dyplomu magistra filozofii [w:] E. Beynar-Czeczott, Mój ojciec Pawet Jasienica, s. 33.

${ }^{15}$ Instytut Pamięci Narodowej, Biuro Udostępniania (dalej: IPN BU), 0204/19/1, L. L. Beynar, „Życiorys”, Kraków, 5 lipca 1948, k. 46.

16 A. Franaszek, Miłosz. Biografia, Kraków 2011, s. 236, 259.

${ }^{17}$ L. Beynar, Zygmunt August na ziemiach dawnego Wielkiego Księstwa Litewskiego, Wilno 1935; tenże, Ziemie pótnocno-wschodnie Rzeczypospolitej Polskiej za Sasów, Wilno 1939.

${ }^{18}$ Por.: W. Chudy, Józefa Mackiewicza filozofia człowieka i polityka, Archiwum Emigracji. Studia - Szkice - Dokumenty 2003 z. 5/6, s. 161-163.

${ }^{19}$ W. Bolecki, Antypolityczny antykomunista. Sylwetka ideowa Józefa Mackiewicza, [w:] Myśl polityczna na wygnaniu. Publicyści i politycy polskiej emigracji powojennej, red. A. Friszke, Warszawa 1995, s. 83-85. 
polityczne novum [...] polega[ło] na cynicznym traktowaniu wszelkich zobowiązań, na traktowaniu każdego działania jedynie jako — wygodnej w danej chwili — taktycznej rozgrywki, której ostatecznym celem jest utrzymanie władzy i jej ekspansja ${ }^{20}$.

$\mathrm{Na}$ światopogląd Beynara miał niezaprzeczalny wpływ ówczesny mentor wileńskich studentów — profesor Marian Zdziechowski — znany w kręgach akademickich ze swoich antytotalitarnych poglądów; m.in. był zdecydowanym przeciwnikiem ideologii komunistycznej pobliskich Sowietów i wszystkich innych przejawów totalitaryzmu, a więc także polskiego autorytaryzmu w wykonaniu sanacji; stąd zapewne odmowa wpływowym kręgom warszawskim, by wysunęły jego kandydaturę w wyborach na prezydenta po przewrocie majowym ${ }^{21}$. On był autorem słynnej zasady, w myśl której pretensje nacjonalistyczne tym są większe, im zasługi dla kultury narodowej mniej$\mathrm{sze}^{22}$. Leon świadomie wybrał historię, bo na przekór temu, co głosił o ludziach XX wieku, chciał podźwignąć spadek po rzeczywistej historii: ,tej urwanej w roku 1795 przez ostateczny rozbiór Rzeczypospolitej Obojga Narodów"23. Ponadto tkwiło w nim przekonanie, że Polacy, jako spadkobiercy i „dziedzice najstarszej kultury” na tej połaci kontynentu mają moralny obowiązek przypominać i ratować to, co do uratowania pozostało ze wspólnego dorobku wielu równoprawnych narodów Rzeczypospolitej ${ }^{24}$.

I tu pojawia się jeszcze jeden punkt styczny poglądów dla obu spadkobierców Pierwszej Rzeczypospolitej — urzeczenie i szacunek dla niegdysiejszego wielonarodowego Wielkiego Księstwa Litewskiego - kierunek myśli, zwany z czasem „ideą krajową”. „Krajowcy”, których najbardziej znanym przedstawicielem był właśnie Józef Mackiewicz, uznawali Litwę za ojczyznę wielu narodów:

społeczeństwo tych ziem to amalgamat krwi litewskiej, polskiej, białoruskiej, przemieszany z Żydami, Tatarami, Karaimami, Starowiercami ${ }^{25}$.

Żaden z tych narodów z osobna, a jedynie wszystkie razem miały prawo do niego, do kraju bez granic narodowych, językowych i religijnych. Litwa historyczna, a nie etniczna była esencją ich poglądów. Stąd też m.in. negowanie pojęcia „kresy” jako a priori określającego cząstkę jakiejś całości — w tym wypadku region Drugiej Rzeczypospolitej. Michał Römer, mentor „krajowców” (obok Ludwika Abramowicza), już w momencie kształtowania się obu państw w 1919 roku notował w swoim Dzienniku:

Litwa jest krajem mieszanym, krajem o odrębnych strefach przewagi tej lub innej kultury narodowej, [...] Wilno jest w równej mierze stolicą współżycia, nie zaś panowania, wiązadłem kooperacji kulturalnej ludów krajowych, nie zaś narzędziem podporządkowania jednych drugim! ${ }^{26}$.

Jasienica nigdy wprost nie deklarował przynależności do „krajowców”, nie sposób

${ }^{20}$ Tenże, Ptasznik z Wilna, s. 116.

${ }^{21}$ S. Kościałkowski, Marian Zdziechowski jako uczony, myśliciel i człowiek, Spotkania 1981 nr 15, s. 78.

${ }^{22}$ P. Jasienica, Pamiętnik, s. 91.

${ }^{23}$ Tamże, s. 88.

${ }^{24}$ Tamże, s. 91.

${ }^{25}$ W. Bolecki, Antypolityczny antykomunista, s. 84-85.

${ }^{26}$ Biblioteka Litewskiej Akademii Nauk, Dział Rękopisów, M. Römer, Dziennik, t. 26, k. 187; zob. też: R. Miknys, Wilno i Wileńszczyzna w koncepcjach Michała Romera i krajowców, [w:] Europa nieprowincjonalna. Przemiany na ziemiach wschodnich dawnej Rzeczypospolitej (Białoruś, Litwa, Łotwa, Ukraina, wschodnie pogranicze III Rzeczypospolitej Polskiej) w latach 1772-1999, pod red. K. Jasiewicza, Warszawa-Londyn 1999, s. 57-65. 
jednak interpretować jego słów i zachowań, inaczej niż właśnie jako wyrazu pełnej akceptacji takich poglądów. W czasie okupacji uprawiał swoistego rodzaju intelektualny masochizm, gdy na jego oczach umierała Wileńszczyzna wielonarodowa i wielokulturowa, ,w tragicznej i ślepej walce wszystkich przeciwko wszystkim, [kiedy] dogasały polityczne tradycje Rzeczypospolitej Obojga (a raczej wielu) Narodów" ${ }^{27}$, w chwilach wolnych od pracy zaglądał do kościoła Bernardynów, odszukiwał pamiątki tradycji Trylogii - Polski XVII wieku — jedna z tablic nagrobnych, z 1646 roku, pochodziła $\mathrm{z}$,,tamtej strony «smugi cienia» historii”. Po latach pisał:

gorzka to była satysfakcja intelektualna patrzeć na tę pamiątkę w dobie okupacji. A jednak uprawiałem to samoudręczenie i często przychodziłem patrzeć na nią ${ }^{28}$.

Nad grobem swojego pobratymcy z Wilna, „żubra kresowego”, przyjaciela — Stanisława Cata-Mackiewcza - mówił:

Rzeczpospolita Obojga Narodów, pierwsze w dziejach państwo dla wielu narodowości. To jego ukochane Wilno w r. 1655 w chwili swego upadku i katastrofy liczyło dwadzieścia trzy kościoły katolickie, dziesięć cerkwi unickich, dwie prawosławne, świątynie ewangelickie: luterańską i kalwińską, bożnice Starego Zakonu, meczet tatarski. Już wtedy w XVII wieku mówiono, że nigdzie na świecie nie czci się Boga w sposób tak rozmaity jak w Wilnie.

Prawdziwi dziedzice tych tradycji są odporni na ksenofobię, na odruchy wrogości wobec narodów, z którymi sąsiadować im przyszło o miedzę lub na kontynencie ${ }^{29}$.

I jeszcze na koniec tych rozważań, dotyczących czasów dwudziestolecia międzywojennego i wspólnych obu mieszkańcom Wilna poglądów, warto wspomnieć o ich stosunku do religii, a ściślej mówiąc - katolicyzmu. Powiedzieć o nim chłodny, to mało — raczej mocno krytyczny. Jasienica, który po wojnie schronił się pod skrzydłami metropolitarnymi ks. Adama Sapiehy, żartował, że zmusiło go do tego zwycięstwo komunizmu w Polsce, mimo osobiście libertyńskich poglądów ${ }^{30}$. Ale już bez żartów pisał w Polsce Piastów:

Polacy są narodem katolickim, ale ich stosunek do wiary polega na uczuciu i przywiązaniu do tradycji. Tyle razy już pisano o braku u nas głębszych zainteresowań religijnych. I dziś jeszcze przeciętny polski katolik nie zna większości dogmatów i wskutek tego - wzorem swego przodka z XIII wieku — właściwie nie wie, w co wierzy ${ }^{31}$.

Mackiewicz, w proteście przeciwko dyskryminacyjnej polityce sanacji wobec prawosławnych na Kresach, porzucił katolicyzm, przechodząc do kościoła dyzunitów w 1938 roku, czym wielokrotnie szczycił się wśród znajomych ${ }^{32}$.

Podczas gorącego lata 1939 roku drogi obu Wilnian rozeszły się ostatecznie, choć paradoksalnie właśnie wtedy po raz pierwszy nawiązali ze sobą dialog.

Już dwa dni po wkroczeniu Sowietów do Polski bracia Mackiewiczowie opuścili Wilno i schronili się w Kownie na terytorium Republiki Litewskiej, tam też przeżyli cały okres kampanii wrześniowej i tzw. pierwszej okupacji sowieckiej. Józef opubli-

${ }^{27}$ P. Jasienica, Krew pobratymcza, Twórczość 1956 nr 1, s. 111; przedruk w: tenże, Tylko o historii, Warszawa 2009, s. 140.

${ }^{28}$ Tamże.

${ }^{29}$ Cyt. za: A. Niemczykowa, Moje Wilno, [w:] Europa nieprowincjonalna, s. 96.

${ }^{30}$ Z. Żbikowski, Kapitan martwej armii - Pawet Jasienica, Życie (Warszawa) 14.04.2001.

${ }^{31}$ P. Jasienica, Polska Piastów, Warszawa 2007, s. 210.

${ }^{32}$ W. Bolecki, Ptasznik z. Wilna, s. 74. 
kował w gazecie litewskiej artykuł Mes Vilnieciai (My, Wilnianie...), w którym przedstawił swoje poglądy na „krajowość” Wileńszczyzny. Miało to być nowe otwarcie w stosunkach polsko-litewskich, jak napisała redakcja: „smuga światła [rzucona] na ogół tych zagadnień" ${ }^{33}$. Mackiewicz — podpisany tam jako Juozas Mackievičius wyrażał akceptację przejęcia Wilna przez wojska litewskie, ku obopólnej — polsko-litewskiej - korzyści, nazwał to „wspólnotą interesów”. Poddał krytyce przedwojenną politykę sanacji, szczególnie w stosunku do mniejszości narodowych. Artykuł odniósł negatywny skutek, szczególnie w środowisku polskich żołnierzy internowanych na Litwie, odmawiali mu oni nie tylko prawa wypowiadania się w imieniu ogółu Polaków, ale też zarzucali zachowanie niegodne Polaka ${ }^{34}$.

Mackiewicz wrócił do Wilna wraz z przejęciem miasta przez władze litewskie i, jak natychmiast zauważył, płonne okazały się jego marzenia o wspólnym „kraju”:

Omyliłem się kompletnie. Społeczeństwo polskie zachowało się wrogo wobec faktu wkroczenia wojsk litewskich. Społeczeństwo zaś litewskie uczyniło wszystko, aby wrogość tę spotęgować i rozłam pogłębić ${ }^{35}$.

W mieście natychmiast wybuchły zamieszki wywołane albo nagłą drożyzną w sklepach (i wymianą złotych na lity), albo manifestacjami młodzieży polskiej skandującej: „,precz z Litwą! Dajcie nam Sikorskiego!”36. Uspokojenie przyszło wraz z represjami policyjnymi i puszczeniem na miasto bojówek nacjonalistów litewskich. Potem władze administracyjne przeszły do segregacji mieszkańców na: obywateli, uchodźców i cudzoziemców, wśród których znalazła się zdecydowana większość rodowitych wilnian. Rugowano także Polaków z pracy, zamknięto uniwersytet, przymusowo litwinizowano nazwiska i szyldy, a językiem urzędowym stał się litewski, którego nikt w mieście nie znat $^{37}$.

Ppor. Beynar powrócił do Wilna niemalże w tym samym czasie, co Józef Mackiewicz - w dniu opuszczenia Wileńszczyzny przez Armię Czerwoną. Wcześniej — od 1 do 23 września — w ramach 33. Dywizji Rezerwowej Samodzielnej Grupy Operacyjnej „Narew” bronił granicy północnej od strony Prus Wschodnich. Walczył pod Różaną, Wyszkowem, Włodawą, w widłach Bugu i Narwi ${ }^{38}$. Wiadomość o wkroczeniu Sowietów do Polski dotarła do niego dwa dni po agresji — 19 września 1939 roku — kiedy najwyższych władz państwowych nie było już w kraju. Beynar zapamiętał tę chwilę dobrze i odtworzył po latach:

\footnotetext{
${ }^{33}$ Pierwodruk artykułu: „Lietuvos Žinios” („Wiadomości Litwy”) 14.10.1939; tekst artykułu przetłumaczył na j. polski i opublikował C. Chlebowski, Tygodnik Powszechny 1989 nr 41, s. 4. Artykuł ten Mackiewicz napisał już po podpisaniu układu między Moskwą a Kownem o przejęciu Wileńszczyzny przez Litwę (10 października 1939), a przed formalnym wkroczeniem wojsk litewskich do Wilna (28 października 1939).

${ }^{34}$ W. Bolecki, Ptasznik z Wilna, s. 167-168.

${ }^{35}$ J. Mackiewicz, Prawda w oczy nie kole, Londyn 2011, s. 95.

${ }^{36}$ M. Krzepkowski, Wspomnienia dziennikarza z czasów okupacji (Wilno 1939-1941), Zeszyty Historyczne 1978 z. 45, s. 148-149.

${ }^{37}$ K. Tarka, Epigoni Wielkiego Księstwa Litewskiego. Krajowcy wileńscy 1939-1940, Zeszyty Historyczne 1993 z. 103, s. 103.

${ }^{38}$ Na temat walk 33. i 41. Dywizji Piechoty (w których służył Beynar) zob.: T. Zieleniewski, Niedoszła bitwa nad Narwia w 1939 r., Wojskowy Przegląd Historyczny 1971 nr 1; tenże, 33 Dywizja Piechoty rez. w bitwie nad Bugiem we wrześniu 1939 r., Wojskowy Przegląd Historyczny $1969 \mathrm{nr} 3-4$.
} 
Tego samego dnia doszedłem do przekonania, że nie ma takiej siły na świecie, która by mogła (i chciała) przywrócić Polsce jej dotychczasowe granice wschodnie. Francuzi zaś i Anglicy pierwsi łatwo pogodzą się z faktem dokonanym. Zwierzyłem się dowódcy kompanii, uczciwemu i odważnemu żołnierzowi, który natychmiast nazwał moje wywody bzdurą. „To są nasi sprzymierzeńcy” — powiedział, mając oczywiście na myśli Zachód ${ }^{39}$.

Jednostki polskie zmierzały na południe do granicy węgierskiej, otoczone jednak pod Biłgorajem złożyły broń — długa kolumna jeniecka ciągnęła ku oflagom. Na jednym z etapów w Opatowie - dzięki pomocy miejscowych - Beynarowi udało się zbiec, $\mathrm{z}$ niewoli, ruszył natychmiast do Wilna ${ }^{40}$.

Mackiewicz kontynuował na „Litwie Smetonowskiej”41 — jak nazywali ją teraz Polacy — misję „krajowości”: założył „Gazetę Codzienną”, w której przekonywał, że przed Polakami istnieje tylko jedna alternatywa - albo Wilno litewskie, albo sowieckie - co faktycznie nie było żadnym wyborem, gdyż odpowiedź wydawała się oczywista $^{42}$. Dużo miejsca poświęcał „,wojnie zimowej” między Finlandią a ZSRR - co wobec jego antysowieckich poglądów było oczywiste. Niestety zaangażował się także w propagowanie na łamach swojego pisma endeckich broszur antysanacyjnych, które znawcy przedmiotu określają mianem pamfletów politycznych, pisanych wulgarnym językiem i uwłaczających godności narodowej Polaków ${ }^{43}$. Sam Miłosz uważał, że właśnie te broszury - których współautorstwo przypisywał Mackiewiczowi — stały się zarzewiem konfliktu z Polskim Podziemiem: „[...] od tej broszury zaczyna się, moim zdaniem, seria oskarżeń o zdradę, mających ścigać Józefa Mackiewicza" ${ }^{44}$.

Ale dla władz litewskich, coraz bardziej nacjonalistycznych, nawet sam Mackiewicz okazywał się za mało litewski. W czerwcu 1940 roku Sowieci powtórnie wkroczyli do Litwy, rozpoczynając tzw. drugą okupację, tym samym jakakolwiek wolna prasa - polska czy litewska - przestała się ukazywać. „Gazetę Codzienną” połączono z innymi pismami, tworząc jedną, komunistyczną „Prawdę Wileńską”. Mackiewicz rozpoczął egzystencję pracownika fizycznego: drwala i furmana, na propozycję NKWD, by wrócił do dziennikarstwa — odmówił — uciekł i znalazł schronienie w le-

${ }^{39}$ P. Jasienica, Fiat voluntas, Twórczość 1959 nr 7, s. 119, [rec.:] S. Mackiewicz, Zielone oczy, Warszawa 1958; przedruk: tenże, Tylko o historii, s. 254.

${ }^{40}$ Tenże, Wrzesień i Sierpień, Tygodnik Powszechny 1949 nr 19, s. 1.

41 „Litwa Smetonowska” — od nazwiska prezydenta Republiki Litewskiej, a w rzeczywistości długoletniego dyktatora Litwy, Antanasa Smetony, 1874-1944).

42 J. M., Będziemy mówili prawdę, Gazeta Codzienna 25.11.1939, s. 1-2.

${ }^{43}$ Chodzi o prace Piotra Kownackiego, przedwojennego nacjonalisty, Gdyby Dziadek żyt... i Rachunek sumienia; zob.: Z. Ponarski, Józef Mackiewicz - fakty i mity, Archiwum Emigracji. Studia - Szkice - Dokumenty 2003 z. 5/6, s. 282-284; P. Łossowski, Litwa a sprawy polskie 1939-1940, Warszawa 1982, s. 252; S. Lewandowska, Życie codzienne Wilna w latach II wojny światowej, Warszawa 1997, s. 277.

${ }^{44}$ Cz. Miłosz, Abecadto, Kraków 2010, s. 182. W tej samej książce Miłosz pisze: „Kiedy miasto objęły władze litewskie, oskarżenia o kolaborację z okupantem ściągnęła na siebie «Gazeta Codzienna» Józefa Mackiewicza, wiernego ideologa «krajowców». Dalsze pomówienia tego pisarza - o współpracę tym razem z Niemcami, moim zdaniem nieuzasadnione - wynikały z tego pierwszego posądzenia o zdradę, przy czym szczególnie gorliwie podtrzymywali to w podziemiu «narodowcy», Fedorowicz i Ochocki” (s. 129-130). W wypowiedziach Miłosza występuje pewna sprzeczność: Mackiewicz wespół z endekami pisze broszury antysanacyjne promowane na łamach jego „Gazety Codziennej”, po czym zostaje on uznany za wroga numer jeden przez endeków za prowadzenie tejże gazety? 
$\mathrm{sie}^{45}$. Tymczasem już wtedy — w lutym i marcu 1940 roku — rząd emigracyjny RP (w Angers) analizując problem Wileńszczyzny zwrócił uwagę na szkodliwą dla interesu Polski działalność Józefa Mackiewicza; wezwał nawet Stanisława Cata-Mackiewicza do potępienia brata ${ }^{46}$. W raporcie do premiera i Naczelnego Wodza gen. Sikorskiego znalazły się oskarżenia wobec „krajowców”, że swoimi działaniami „paraliżują zorganizowanie jednolitego oporu ze strony polskiej ${ }^{47}$. Informacje pochodziły od komórki polskiego podziemia, określające pismo jako wybitnie filolitewskie ${ }^{48}$.

W tym krótkim, bo niewiele ponad półrocznym epizodzie, władzy litewskiej na Wileńszczyźnie Beynar dbał przede wszystkim o dobro rodziny, pracował fizycznie jako pomocnik murarza, stróżował w nocy pilnując gminnych nieruchomości i pracował w tartaku, gdzie w wypadku stracił środkowy palec lewej dłoni ${ }^{49}$. O wyjeździe za granicę - podobnie jak niektórzy wilnianie, np. bracia Mackiewiczowie — nigdy nie myślał, obywatelstwa litewskiego też nie przyjął, żył w swoim mieście na prawach obcokrajowca, stracił też pracę w rozgłośni radiowej ${ }^{50}$. Wiosną 1940 roku zaciągnął się do Związku Walki Zbrojnej (ZWZ), późniejszej Armii Krajowej (AK); przybrał konspiracyjny pseudonim „Nowina”, W1. Włączył się w działalność komórki Biura Informacji i Propagandy (BIP-u), redagował pisma konspiracyjne, których treść pochodziła z nasłuchu radiowego rozgłośni alianckich. Miał bezpośredni kontakt z najważniejszą postacią wileńskiej konspiracji - Komendantem Okręgu Wileńskiego AK, płk. Aleksandrem „Wilkiem” Krzyżanowskim. Spotkali się kilkakrotnie, Beynar, który otrzymał polecenie analizowania wzajemnych relacji między Polakami, Litwinami i Niemcami (nowymi okupantami), miał też prowadzić akcje ulotkowe przeciwdziałające fali wyjazdów Polaków na roboty do Niemiec ${ }^{52}$.

22 czerwca 1941 roku rozpoczęła się operacja „Barbarossa”, Wehrmacht wkroczył na Litwę zabierając ziemie dotychczasowego sprzymierzeńca, zaczynała się nowa okupacja, której skutków nikt nie był w stanie przewidzieć. Już w lipcu 1941 roku ukazał się w Wilnie pierwszy numer „Gońca Codziennego”, pisma w języku polskim wydawanego pod protektoratem niemieckim, z artykułem Józefa Mackiewicza Przeżyliśmy upiorna rzeczywistość - o okupacji sowieckiej ${ }^{53}$. Następnie opublikował wspo-

${ }^{45}$ W. Bolecki, Ptasznik z. Wilna, s. 193-195.

46 „Na posiedzeniu Rady Ministrów z 1 marca tegoż roku [1940] ówczesny podsekretarz stanu w Ministerstwie Opieki Społecznej Karol Popiel domagał się wezwania przebywającego na uchodźstwie znanego publicysty Stanisława Cat-Mackiewicza do potępienia postępowania jego brata Józefa, który w zajętym przez Litwinów Wilnie wydawał podówczas «Gazetę Codzienną», negatywnie nastawioną do przedwrześniowej Polski"; W. Rojek, Kwestia Wileńszczyzny w pracach rządu RP na uchodźstwie od października 1939 do lipca 1941 roku, [w:] Europa nieprowincjonalna, s. 69.

${ }^{47}$ K. Tarka, Epigoni Wielkiego Księstwa Litewskiego, s. 119.

${ }^{48}$ Studium Polski Podziemnej w Londynie, relacja Teresy Jurgielewiczowej.

${ }^{49}$ IPN BU, 0204/19/1, „Protokół przesłuchania podejrzanego Beynara Leona Lecha”, Warszawa, 12 lipca 1948, k. 54.

${ }^{50}$ IPN BU, 0204/19/1, L. L. Beynar, „Życiorys”, Kraków, 4 lipca 1948, k. 8.

${ }^{51}$ IPN BU, 0204/19/1, L. L. Beynar, ,Życiorys”, Kraków, 5 lipca 1948, k. 46-47.

52 IPN BU, 0204/19/1, „Protokół przesłuchania podejrzanego Beynara Leona Lecha”, Warszawa, dnia 13 lipca 1948, k. 57-58.

${ }^{53}$ Według Teresy Jurgielewiczowej — tłumaczki w „Gońcu” i agentki podziemia — grono redakcyjne „Gońca Codziennego” składało się z trzech osób: Czesława Ancerewicza (redaktor naczelny), Józefa Mackiewicza i Eugeniusza Kotlarewskiego; zob.: G. Mazur, O Józefie Mackiewiczu - inaczej, Więź $1991 \mathrm{nr} 6$, s. 86. 
mnienia z Mojej dyskusji z NKWD, i w sierpniu tego roku dokonał krytycznej analizy radziecko-brytyjskiego porozumienia $w$ ramach koalicji antyhitlerowskiej ${ }^{54}$. Wszystkie artykuły miały ewidentnie antybolszewicki charakter ${ }^{55}$.

Po drugiej stronie barykady znalazł się wówczas ppor. „Nowina”, który, podobnie jak Mackiewicz, zajmował się publicystyką, tyle tylko, że w redagowanych przez niego podziemnych pismach informowano o ogólnej sytuacji wojennej i podtrzymywano ducha polskości na okupowanej ziemi. Polemizowano w nich $\mathrm{z}$ autorami pism o charakterze nacjonalistycznym:

pisywałem rozmaite artykuły i ulotki dla wydawnictw Armii Krajowej, głoszące, iż okupantem są Niemcy hitlerowskie, nie zaś głupi „kałakutasy” [dosłownie — indyki; w przenośni - litewscy policjanci]. Takie rzeczy trzeba było propagować i tłumaczyć ludziom, codziennie poniewieranym za odzywanie się mową Adama Mickiewicza ${ }^{56}$.

Od lata 1941 roku analizował teksty Mackiewicza w „Gońcu Codziennym” i natychmiast rozpoczął z nimi polemikę, która trwała jeszcze wiele lat po wojnie - aż do śmierci obu adwersarzy. Szczególnie niepokoiły go głosy zachęty do współpracy z nazistami w imię krucjaty antybolszewickiej:

Natomiast wobec Narodu Polskiego bluźnierstwem byłby zarzut, że nie pragnie on z całym światem cywilizowanym zniszczenia raz na zawsze, wypalenia ogniem i żelazem przeklętego systemu, by wreszcie przestał zagrażać ludzkości. W tej ostatniej wojnie wolałbym raczej nie być Polakiem, niż skalać się sojuszem z największym wrogiem świata - bolszewickim państwem ${ }^{57}$.

Dlaczego bolszewizm był gorszy od nazizmu? Dlaczego sojusz aliantów z ZSRR był mrzonką, a nawet złem? Mackiewicz tłumaczył:

Bolszewizm jest wrogiem przede wszystkim i nade wszystko, bo jest wrogiem nr 1 każdego narodu. O ile wróg, że się tak wyrazimy „,normalny”, niszczy przede wszystkim państwo swego przeciwnika, o tyle bolszewizm pokonując państwo, niszczy jednocześnie naród, ewentualnie narody to państwo zamieszkujące, ich dobra duchowe, ich ideały narodowe. I to niszczy w sposób gruntowny, specyficzna metodą podporządkowania polityki narodowościowej systemowi komunistycznemu. Jeżeli się mówi o „bolszewickiej zarazie", to nie z zamiarem użycia obraźliwego słowa, a raczej dosłownie ściśle. [...]

Mówmy o faktach. A faktem jest, że z jednej strony walczą Niemcy, z drugiej koalicja anglo-sowiecka. Jakiż byłby też rezultat takiego niemożliwego zwycięstwa? Dziś przegrała prestiżowo i przegra militarnie w górach Norwegii, w cieśninach Skageraku, we Flandrii, w Jugosławii, Grecji, na Krecie. Przegra wszędzie, nie wygrawszy ani jednej bitwy, ani jednej operacji wojennej przeciwko Niemcom. A więc triumfatorem w zwycięskiej koalicji anglo-sowieckiej nie byłby król Jerzy VI, tylko Józef Wissarionowicz Stalin. Jemu przypadłaby chwała, w aureoli której wjeżdżał ongiś do Paryża cesarz Aleksander I.

Co by nastąpiło dalej, nietrudno przewidzieć. Być może nastąpiłoby nawet prze-

${ }^{54}$ W. Bolecki, Ptasznik z Wilna, s. 196.

55 Według Kazimierza Orłosia, literata i siostrzeńca Józefa Mackiewicza, publikacje w „Gońcu Codziennym” miały charakter jedynie antysowiecki, a nie antypolski; zob.: K. Orłoś, W obronie zdrowego rozsadku, Kultura Niezależna $1988 \mathrm{nr} 41$; tenże, Kto jest kolaborantem?, Gazeta Wyborcza 19.07.1991.

${ }^{56}$ P. Jasienica, Krew pobratymcza, s. 138.

57 [J. Mackiewicz] J. M., Przeżyliśmy upiorna rzeczywistość, Goniec Codzienny, lipiec 1941, nr 2, s. 2. 
mianowanie Point d'Aleksandre III w Paryżu na Point Staline, ale już nie po to, aby po nim chodzili Francuzi, tylko obywatele Francuskiej Republiki Rad...

O losie Polskiego Narodu moglibyśmy w tym miejscu nawet nie wspominać. Jego los byłby przypieczętowany może na wieki, a może na zawsze łącznie z losem innych narodów Europy Wschodniej... [...]

Dlatego jestem bardzo, ale to bardzo głęboko przekonany, że w sytuacji z roku 1941 zwycięstwo koalicji anglo-sowieckiej byłoby dla Polaków największą klęską, jaka nie tylko ich w tej wojnie spotkać mogła, ale klęską przewyższającą wszystkie dotychczasowe na przestrzeni dziejów ${ }^{58}$.

Dla Jasienicy było nie do pomyślenia, aby jedno zło zwalczać drugim, nie przekonywały go argumenty o zakończeniu wywózek w głąb Rosji wraz z pojawieniem się władzy niemieckiej — jego filozofia była prosta, każda współpraca z jednym lub drugim totalitaryzmem była zbrodnią, i to nie tylko przeciwko narodowi polskiemu, ale także tych wszystkich narodów, które chciały spokojnie egzystować:

Okupacja na Wileńszczyźnie nosiła charakter antypolski, antylitewski, antybiałoruski, antyżydowski - tych ,anty” wymienić można dokładnie tyle, ile tam mieszkało narodowości ${ }^{59}$.

Jeszcze zaraz po wojnie przypominał, że naród polski w większości zdał egzamin z ,solidarności narodowej” i także solidarności ogólnoludzkiej, wyrażającej się w pomocy Żydom i rosyjskim jeńcom wojennym. A właśnie w Wilnie, za rzucenie kromki chleba jeńcowi bolszewickiemu groziło zastrzelenie — jednego i drugiego ${ }^{60}$.

W podziemnym piśmie „Dla Polski”, ${ }^{61}$ z grudnia 1941 roku, wszystkim, którzy widzieli tylko jednego okupanta - Sowietów — nie dostrzegając eksterminacyjnych działań Niemców, odpowiadał w artykule Pseudokrucjata i jej heroldowie:

Naprawdę, jakąż pogardę dla masy ludzkiej żywić musi arcymistrz propagandy dr Goebbels, skoro liczy na powodzenie tak grubego chwytu! Nikt nie przeczy, że Niemcy wypędzili stąd bolszewików, ale czemuż nikt nie pyta, kto tu ich wpuścił. Przecież nie uczynili tego Anglicy ani Amerykanie, ani Polacy. To minister Rzeszy, Ribbentrop, podpisał układ, oddający w moc czerwonych komisarzy tysiące kilometrów kwadratowych ziemi i miliony Europejczyków, a oddziały wojsk niemieckich prezentowały broń nad Bugiem przed kompaniami czerwonej armii. To egoistyczna i antyeuropejska polityka wojenna Hitlera uczyniła Stalina władcą narodów na międzymorzu bałtycko-czarnomorskim. [...]

Czymże bowiem są Niemcy w chwili obecnej? Najgroźniejszym wrogiem Europy, który dziś walczy wprawdzie z Rosją, ale jednocześnie sam ogniem i mieczem wprowadza takiż sam wschodni despotyzm wszędzie, gdziekolwiek dociera oręż niemieckiego żołdaka. Przejawy zewnętrzne są różne, ale istota rzeczy - ta sama. Fałsz i obłuda, kult materialnej siły i tępienie indywidualizmu oto wspólne dziedzictwo Rosji i Prus po dawnym Bizancjum, politycznym mistrzu Krzyżaków. Niemcy na jawie śnią

58 [J. Mackiewicz] J. M., To dopiero byłaby klęska..., Goniec Codzienny, sierpień 1941, nr 16; cyt. za: W. Bolecki, Ptasznik z Wilna, s. 207-210.

${ }^{59}$ P. Jasienica, Krew pobratymcza, s. 139.

${ }^{60}$ Tenże, Warto pogadać, Tygodnik Powszechny $1947 \mathrm{nr}$ 9, s. 5.

61 „Dla Polski” było pismem kontynuującym tradycje „Jutro Polski” księdza Henryka Hlebowicza. Ukazały się zaledwie trzy numery z przełomu 1941-1942 roku. Jedyny zachowany pochodzi z grudnia 1941 roku. Innych numerów nie było, gdyż Niemcy szybko wpadli na trop redakcji; zob.: B. Wiaderny, Pawet Jasienica, s. 58. Na temat innych pism konspiracyjnych redagowanych przez Jasienicę, zob.: G. Mazur, Biuro Informacji i Propagandy SZP-ZWZ-AK 1939-1945, Warszawa 1987, s. 231. 
dziś o tępieniu narodów i przesiedlaniu ich poza Ural. Wyraźnie mówią o tym oficjalne i nieoficjalne wynurzenia Hitlera i Rosenberga. A los ten czeka przede wszystkim ludność ziem nadbałtyckich określonych przez Hitlera jako „kraj kultury niemieckiej”. Kogo nie nauczyły przykłady dawniej wytępionych narodów, ten niech się przyjrzy losowi Polaków na ziemiach wcielonych do Rzeszy albo - Francuzów w Alzacji i Lotaryngii. Niechże przeczyta opisy masowych wysiedleń, wcale różnych od praktyk NKWD. Wprawdzie do Azji Niemcy nikogo jeszcze nie wywieźli, ale tylko dlatego, że w niej dotąd nie rządzą. Gdyby się to jednak stało, pojechalibyśmy na Ural wszyscy: i my Polacy, i wy Litwini, Łotysze i Białorusini, i każdy w ogóle, kto nie należy do „herrenvolku”.

To chcemy powiedzieć tym, którzy swe narodowe plany budują na niemieckim fundamencie. Polski żołnierz, walczący z Niemcami, najgroźniejszym dziś wrogiem wolności w Europie, walczy „za naszą wolność i waszą”.

Ale mamy też parę słów dla kilku wileńskich Polaków, którzy się na ochotnika zgłosili jako heroldowie niemieckiej „krucjaty”. Nie chodzi tu o umiejętnie reklamującego się p. Ancerewicza, bo drobiazgu ludzkiego nigdzie nie brakuje. Gorzej natomiast, że właśnie w Wilnie znaleźli się ludzie wybitniejsi, o znanych nazwiskach, którzy poszli na współpracę z Niemcami. Tego dotąd w całej Polsce nie było. Niechlubny wyjątek stanowią wilnianie pp. Wacław Gizbert-Studnicki, Józef Mackiewicz (ten sprzeniewierza się swemu narodowi już po raz drugi) oraz ich nieliczni poplecznicy.

P. Studnicki zbiera materiały do dziejów naszej martyrologii za czasów bolszewickich i w niemieckiej gazecie, wydawanej po polsku („Goniec Codzienny”) wyraża żal, że nie bierzemy udziału w tzw. „krucjacie”. Tak jest, trzeba dobrze pamiętać o cierpieniach narodu polskiego, ale jego krew i jego łzy policzymy w wolnej Polsce i nie na użytek niemieckiej propagandy. Co do krucjaty — to jedynie dwa narody zasługują na miano krzyżowców i obrońców chrześcijaństwa w walce z bolszewizmem: Polacy i Finowie. To my i tylko my zatrzymaliśmy pochód bolszewicki w r. 1920, w okresie heroicznego komunizmu. To my powtórnie skrzyżowaliśmy z nimi szpady w strasznych dniach września 1939 r. Zaszczyt ten dzielić z nami mogą jedynie żołnierze Finlandii.

Panowie z „Gońca” wiedzą to chyba dobrze, ale uważają widocznie, że łatwiej zdobyć patent na patriotę, pisząc o wywózkach i Kazachstanie. Panowie! Nie szargać tego słowa: Kazachstan. Ono oznacza zawsze ludzkie nieszczęście, a często i ludzki heroizm. Zesłańcy żyją i powrócą, a wtedy popatrzcie im w oczy, wy, którzy służycie tym, co jednym pociągnięciem pióra zaprzedali ich w niewolę. I wy pomniejsi, co Niemcom nadskakujecie w sposób niegodny ludzi wolnych ${ }^{62}$.

W listopadzie 1941 roku Józef Mackiewicz i Czesław Ancerewicz znaleźli się na liście podziemia osób kolaborujących z okupantem - w stosunku do Mackiewicza zanotowano: „Na tle zespołu redakcyjnego wyróżnia się ujemnie Józef Mackiewicz, przez swe wybitnie germanofilskie nastawienie" ${ }^{\text {63 }}$. Wyrok wydano ostatecznie na przełomie 1942 i 1943 roku. Na początku 1943 w dwunastym numerze pisma konspiracyjnego „Niepodległość” ukazał się artykuł Trzej panowie z „Gońca Codziennego”, w którym ponownie publicznie napiętnowano autorów niemieckiej gadzinówki ${ }^{64}$. Mackiewiczowi zarzucano szczególną rolę w „lokajskim ruchu prolitewskim” i prowadzenie gazety będącej na ,żołdzie szowinistów litewskich" ${ }^{65}$. Według obrońców Józefa Mackiewicza - i jego samego - właśnie ten tekst zapoczątkował nagonkę na trójkę publicystów i posłużył za koronny dowód zdrady w podziemnym procesie Sądu Spe-

62 [L. L. Beynar], Pseudokrucjata i jej heroldowie, Dla Polski 1941 nr 2, s. 3, cyt. za: G. Mazur, O Józefie Mackiewiczu, s. 87-88.

${ }^{63}$ Cyt. za: G. Mazur, O Józefie Mackiewiczu, s. 89.

${ }^{64}$ [J. Wroński], Trzej panowie z „Gońca Codziennego”, Niepodległość $1943 \mathrm{nr} 12$.

${ }^{65}$ Z. Ponarski, Józef Mackiewicz - fakty i mity, s. 300. 
cjalnego AK i na jego podstawie wydano wyrok śmierci ${ }^{66}$. Chronologia wydarzeń ewidentnie przeczy tej linii obrony. Najpierw wyrok — później artykuł; poza tym, trudno sobie wyobrazić, by w logice postępowania procesowego sam artykuł mógłby decydować o życiu lub śmierci oskarżonego.

Artykuł ten zresztą nie był pierwszym, lecz drugim ostrzeżeniem skierowanym do publicystów „Gońca”, jak wiadomo pierwszym był tekst Beynara. Wspominał o tym Jasienica w liście do redakcji „Nowej Kultury” — w nawiązaniu do polemiki Mackiewicza i Kisielewskiego w paryskiej „Kulturze”. Jasienica najpierw cytował słowa Mackiewicza:

Oszczercza nagonka zainaugurowana została gdzieś w okresie „roku katyńskiego” 1943, notatką zamieszczoną w podziemnej wileńskiej „Niepodległości”, a napisaną przez niejakiego Wrońskiego, byłego prowokatora sanacyjnego ZZZ [Związku Związków Zawodowych], agenta bolszewickiego, współpracownika sowieckiej „Prawdy Wileńskiej" w latach 1941-1943, a w dobie okupacji niemieckiej — sekretarza redakcji „Niepodległość”... I od tego czasu pooszło! ${ }^{67}$.

A następnie dopowiadał:

Musze sprostować tę dziwnie nieścisłą wiadomość. Znacznie wcześniej „pooszło!”. „Podziemnym” publicystą, który pierwszy zaatakował Józefa Mackiewicza za kolaborację i wzywanie do kolaboracji z Niemcami byłem ja. Uczyniłem to je sie nią 1941 r., w artykule Pseudokrucjata i jej heroldowie. Artykuł nie był oczywiście podpisany, ale o to nikt chyba nie może żywić do mnie pretensji. Bardzo się wstydzę, ale pamięć jakoś zawodzi i nie jestem całkiem pewien nazwy pisma. Zdaje się „Dla Polski" ${ }^{\circ 8}$.

O los wymienionych kolaborantów zatroszczyło się wileńskie AK. Czesława Ancerewicza ,przykładnie zastrzelili w kruchcie kościoła św. Katarzyny, przeczytawszy mu przed tym wyrok"69 . Co do Józefa Mackiewicza, znanego przecież publicysty przedwojennego „Słowa” i brata znanego Stanisława Cata-Mackiewicza, polityka przebywającego już przy boku rządu na uchodźstwie, było wiele kontrowersji. Nie można było przecież zakładać, że naiwnie nie wiedział co robi; od lutego 1942 roku Komenda Okręgu Wileńskiego AK informowała w akcji ulotkowej, że każdy rodzaj współpracy $\mathrm{z}$ okupantem jest formą kolaboracji ${ }^{70}$. I nie miało tu znaczenia, czy szerzono przy tym poglądy słusznie antybolszewickie, czy nie. Sam fakt uprawiania publicystyki w piśmie niemieckim był ipso facto działaniem proniemieckim i antypolskim zarazem. Po wykonaniu wyroku na Ancerewiczu, Mackiewicz natychmiast zareagował: rozpowszechnił list do Komendy Okręgu Wileńskiej AK, w którym, według jednych, kajał się za swoją niesubordynację, według innych, twierdził, że jest ofiarą pomówień przeciwników politycznych z „obozu bolszewickiego" ${ }^{\text {71 }}$.

Warto tu wspomnieć o jeszcze jednej próbie usprawiedliwienia swoich czynów

${ }^{66}$ Zob.: W. Bolecki, Ptasznik z Wilna, s. 309.

${ }^{67}$ J. Mackiewicz, ,Listy do Redakcji”, Kultura 1957 nr 7-8(117-118), s. 223.

${ }^{68}$ P. Jasienica, „List do Redakcji”, Nowa Kultura 1957 nr 35, s. 11.

${ }^{69}$ P. Jasienica, Moralne zwtoki szlachcica kresowego, s. 195. Los Kotlarewskiego dopełnił się w Warszawie, gdzie zginął w nieznanych do dziś okolicznościach — albo z rąk Polskiego Państwa Podziemnego, albo gestapo.

${ }^{70}$ K. Tarka, Komendant „Wilk”. Z dziejów Wileńskiej Armii Krajowej, Warszawa 1990, s. $48-49$.

${ }^{71}$ G. Mazur, O Józefie Mackiewiczu, s. 92. 
przez Józefa Mackiewicza — w artykule „Redaktor” Bohdan Mackiewicz pisał o ,paradoksalnej sytuacji” jaka zapanowała w redakcji „Gońca”:

„Goniec Codzienny” był de facto robiony i wydawany rękami AK i podziemia cywilnego... Zwłaszcza po zamordowaniu redaktora Ancerewicza blady strach padł na wszystkich pracowników. Jeden przez drugiego starali się nawiązać kontakt z Podziemiem, i przeistoczyć się w tzw. „wtyczkę”. Ze strachu przed podziemnym terrorem, względnie dla asekuracji na przyszłość. Rezultat był taki, że w końcu cały zespół składał się z „wtyczek Podziemia, ${ }^{, 72}$.

Józef Mackiewicz zastosował tu sylogizm, który w przyszłości będzie stosował także w polemice z Pawłem Jasienicą. Z niniejszego wywodu można by wyciągnąć następujący pseudo-logiczny wniosek: 1) „Goniec Codzienny” jest redagowany przez „wtyczki” podziemia; 2) każda wtyczka podziemia jest współpracownikiem AK; 3) tym samym „Goniec Codzienny” jest organem AK. Mackiewicz zapomniał przy tym dodać, że artykuły w „Gońcu” nie tylko podlegały kontroli niemieckiego urzędu propagandy, ale pisane były pod jego dyktando — sam przecież takie kolokwia redakcyjne odbywat ${ }^{73}$.

Próba usprawiedliwienia własnych czynów doprowadziła Mackiewicza do stworzenia błędnego koła zaprzeczeń i wyjaśnień; w 1957 roku skierował list do redakcji paryskiej „Kultury”, w którym napisał, że wobec personalnego ataku pisma podziemnego w istniejących okupacyjnych warunkach nie mógł się bronić:

Oczywiście ani sprostować, ani odpowiedzieć pod własnym imieniem w warunkach ówczesnej konspiracji, i do niej nie należąc, było rzeczą fizycznie niedostępną, niemoż$\operatorname{liwą~}^{74}$.

Jakże to pogodzić z faktem, że fizycznie przecież stykał się z mnóstwem „wtyczek" AK w redakcji pisma — o czym pisał - wystarczyło im powiedzieć, jaka jest prawda. A poza tym, nie jest prawdą — co głosił — że nie miał możliwości obrony, skoro podjął próbę pisemnego przedstawienia swoich racji w liście skierowanym do Komendy Wileńskiej AK po zabójstwie Ancerewicza.

Wielu oficerów sprzeciwiało się wyrokowi wydanemu przez wojskowy Sąd Specjalny przy Okręgu Wileńskim i zaakceptowanemu przez Delegata Rządu w Warszawie. Zaczęły się naciski na „Wilka” Krzyżanowskiego by odwołał wykonanie wyroku. Egzekucji mieli dokonać żołnierze z Kedywu i tam właśnie sprawa natknęła na największy opór. (W Polsce powojennej pojawiły się także niesprawdzone plotki jakoby wykonawcą wyroku miał być sam Beynar ${ }^{75}$.) Po artykule Pseudokrucjata i jej heroldowie Mackiewicz nie umieścił już w „Gońcu” publikacji o charakterze antysowieckim, trudno więc było na tym oprzeć wyrok śmierci. Bezpośrednią przyczyną wydania takiego wyroku wydają się być inne artykuły Mackiewicza, te, w których krytykował porozumienie aliantów z ZSRR i układ Sikorski-Majski. Ostatecznie, jak pisze Jarosław Wołkonowski:

Wcześniejsze artykuły J. Mackiewicza w „Gazecie Codziennej” również uważane były

72 J. Mackiewicz, , Redaktor” Bohdan Mackiewicz, Zeszyty Historyczne 1971 z. 20, s. 170-172.

${ }^{73}$ Studium Polski Podziemnej w Londynie, relacje Lucjana Krawca i Teresy Jurgielewiczowej.

${ }^{74}$ J. Mackiewicz, „Listy do Redakcji”, Kultura 1957 nr 7-8(117-118), s. 223.

${ }^{75}$ G. Eberhardt, Pisarz dla dorostych. Opowieść o Józefie Mackiewiczu, Wrocław 2008, s. 235. Informacja pochodziła od Kazimierza Koźniewskiego, który dowiedział się o tym podobno od Stefana Kisielewskiego, nota bene człowieka, który poznał Beynara już jako Pawła Jasienicę, po wojnie, w redakcji „Tygodnika Powszechnego”. Wcześniej, jak przyznawał, nic o nim nie wiedział. 
za przejaw kolaboracji z okupantami, mimo że w artykułach tych demaskował zbrodnie NKWD i wojsk sowieckich dokonane na Polakach. Te i inne zarzuty (oraz porachunki osobiste) spowodowały, że został wydany na J. Mackiewicza wyrok śmierci. Skazania i wykonania wyroku na J. Mackiewiczu domagał się pion propagandowy BIP-u, natomiast egzekucję powstrzymał pion wojskowy ${ }^{76}$.

Nie zakończyło to przedziwnych losów Józefa Mackiewicza w okupowanym kraju. Wiosną 1943 roku, nieoczekiwanie dla społeczeństwa polskiego, wybuchła sprawa Katynia i w konsekwencji propagowanie wersji niemieckiej. W kwietniu tego roku Mackiewicz otrzymał propozycję od władz Generalnego Gubernatorstwa, akceptowaną przez Berlin, wyjazdu do Katynia. Nie była to pierwsza próba administracji niemieckiej pozyskania dla siebie znanego germanofila, a zarazem zaciekłego przeciwnika bolszewizmu ${ }^{\text {77 }}$. Tym razem jednak okazja była doskonała. Katyń ukazywano w propagandzie goebbelsowskiej jako przejaw barbarzyństwa Wschodu a zarazem humanitaryzmu Zachodu. Doszło więc do paradoksalnej sytuacji, w której Mackiewicz, na którym ciągle ciążył wyrok śmierci wydany przez sąd specjalny AK, zwrócił się do tegoż AK z zapytaniem, czy ma jechać wraz z niemiecką komisją do lasów katyńskich. Odpowiedź była twierdząca, otrzymał też zgodę na opublikowanie relacji z tej „wizyty” na łamach „Gońca Codziennego". Przywiózł dla AK — pouczony przez konspiracyjnych ekspertów, w tym przedwojennych patologów — dwie walizy dowodów zbrodni. Miały one też być argumentem w jego rehabilitacji i anulowaniu wyroku, o co cały czas zabiegał.

W tej sytuacji nastąpiło odroczenie wyroku — pisze Wołkonowski. — Przypadek ten stanowił wyjątek z powodu sprzeciwu strony, która miała wyrok wykonać ${ }^{78}$.

W 1995 roku podczas prac remontowych w wileńskim kościele Bernardynów znaleziono dwie skrzynie z archiwaliami Komendy Okręgu Wileńskiego AK — łącznie ponad dwa tysiące stron. Wśród nich są dokumenty Grupy N podporządkowanej Biuru Informacji i Propagandy Komendy Okręgu Wileńskiego AK, do której obowiązków należało m.in.

obserwowanie i notowanie nazwisk tych osobników spośród Polaków, którzy są zdrajcami sprawy polskiej i znajdują się na usługach naszych wrogów oraz tych, którzy wyparli się swojej narodowości ${ }^{79}$.

${ }^{76}$ J. Wołkonowski, Okręg Wileński Związu Walki Zbrojnej Armii Krajowej w latach 1939 1945, Warszawa 1996, s. 110.

${ }^{77}$ Po kampanii wrześniowej i zajęciu Wilna przez Armię Czerwoną bracia Mackiewiczowie znaleźli się w Kownie, gdzie otrzymali propozycję współpracy z III Rzeszą — odrzucili ją jednak. ,Jesienią 1939 wielu Polaków znalazło się w Kownie. Był wśród nich i Stanisław Cat-Mackiewicz, konserwatysta i konsekwentny zwolennik porozumienia polsko-niemieckiego. Podczas swego pobytu na Litwie Mackiewicz otrzymał ze strony niemieckiej propozycję nawiązania rozmów politycznych. Odpowiedział na to, że niech się Niemcy zgłoszą do przedstawicielstw emigracyjnego rządu polskiego. Można nie być przyjacielem politycznym Cata-Mackiewicza (i ja nim nie jestem), ale w danym wypadku każdy uczciwy człowiek przyzna, że postąpił jedynie słusznie. Zdarzenie to dowodzi, że Niemcy zaraz po ukończeniu kampanii wrześniowej zmierzali do utworzenia jakiegoś rządu polskiego"; [P. Jasienica] (jas.), Prosimy o podanie faktów, Tygodnik Powszechny $1946 \mathrm{nr} 31$, s. 8.

78 J. Wołkonowski, Wileński Okręg AK w świetle nieznanych dokumentów odnalezionych w kościele Bernardynów w Wilnie, [w:] Europa nieprowincjonalna, s. 111. Według Grzegorza Mazura mogło dojść jedynie do zawieszenia wykonania wyroku, gdyż innej możliwości prawnej nie było; zob.: G. Mazur, O Józefie Mackiewiczu, s. 92.

${ }_{79}$ J. Wołkonowski, Wileński Okręg AK, s. 761. 
Na liście znajduje się 750 nazwisk, a pod numerem 372 „a” wpisano nazwisko Józefa Mackiewicza, z uzasadnieniem przestępstwa: „podał się za Litwina, w czasie okup[acji] niem[ieckiej] za Volksdeutscha" ${ }^{\prime 80}$. Wpisu dokonano pomiędzy drugą połową 1943 a pierwszą połową 1944 roku.

Sprawa odnalezionych dokumentów nie została jeszcze do końca wyjaśniona i opracowana przez historyków zajmujących się tą problematyką, dlatego też odpowiedź na pytanie: dlaczego pod takim - nigdy nie wysuwanym wcześniej — zarzutem, został umieszczony na liście Mackiewicz i dlaczego znalazł się tam po misji do Katynia, czyli po nawiązaniu współpracy z AK? - musi poczekać. Według Zenowiusza Ponarskiego - część wpisów ma irracjonalny charakter, nie poświadczony faktami, podobnie bezpodstawny, jak zarzuty wobec Józefa Mackiewicza ${ }^{81}$.

Jasienica widział w działalności młodszego z Mackiewiczów egzemplifikację kryzysu moralnego, jaki dotknął społeczeństwo polskie pod okupacją. W artykule Wrzesień i Sierpień z maja 1949 roku pisał:

Zaraz po wrześniu - a nawet jeszcze podczas kampanii - rozpoczął się u nas kryzys moralny, którego rozmiary i przewidywane skutki wyglądały wprost groźnie. Nie brakowało też objawów ostrej histerii (exemplum: redagowana wówczas w Wilnie przez Józefa Mackiewicza „Gazeta Codzienna”; w ogóle stwierdzić można, że im mniej jakie miasto albo pojedynczy człowiek ucierpieli na wojnie — tym wyższy stopień histerii). Rozmawiałem wtedy z setkami ludzi, widziałem rozmaite rzeczy. To np., że nadal działało prymitywne prawo solidarności narodowej, ale jednocześnie — objawy rzadkie ale wyraźne - Niemiec zaczynał już wyrastać na jakiegoś superarbitra, istotę lepszego gatunku. Rzucało się wtedy w oczy, że najlepiej się trzymają robotnicy i inteligencja która najciężej kryzys odczuła i przeżyła. Ale nad przyszłą orientacją drobnomieszczaństwa, a także części masy chłopskiej, wisiał wielki znak zapytania ${ }^{82}$.

Do końca swojego życia Józef Mackiewicz nie przyznał się do publikowania artykułów w „Gońcu Codziennym”, zaprzeczał także ich istnieniu ${ }^{83}$.

\section{Natione Polonus}

$\mathrm{Na}$ biurku Jasienicy często leżały prace emigrantów polskich, najczęściej tych z kręgu paryskiej „Kultury”. Instytut Literacki w Paryżu był wydawnictwem inteligencji polskiej na uchodźstwie założonym w 1946 roku wspólnymi siłami Jerzego Giedroycia, Zofii i Zygmunta Hertzów oraz Józefa Czapskiego - wszyscy związani z 2. Korpusem Polskim generała Andersa. Początkowo miał swoją siedzibę w Rzymie, a od 1947 roku w podparyskim Maisons-Laffitte. W miesięczniku „Kultura” publikowano prace pisarzy, którzy albo pozostali na obczyźnie by korzystać z wolności twórczej, albo mieszkając w kraju ojczystym nie mieli swobody twórczej. Pierwszym pisarzem mieszkającym w Polsce, a drukowanym w paryskiej „Kulturze” pod własnym nazwiskiem był przyjaciel Jasienicy, a właściwie jego córki Ewy Beynar-Czeczott, Kazimierz Orłoś — siostrzeniec Stanisława Cata-Mackiewicza ${ }^{84}$.

${ }^{80}$ Cyt. za: Z. Ponarski, Józef Mackiewicz — fakty i mity, s. 298.

81 Tamże, s. 299.

${ }^{82}$ P. Jasienica, Wrzesień i Sierpień, s. 1.

${ }^{83}$ W. Bolecki, Ptasznik z. Wilna, s. 202.

${ }^{84}$ E. Beynar-Czeczott, Mój ojciec Pawet Jasienica, s. 82. Pierwszym w ogóle pisarzem krajowym publikującym w „Kulturze”, był Jerzy Andrzejewski, który pisał pod pseudonimem „Apel”; zob.: W oczach pisarzy. Wybór opowieści wojennych (1939-1945), oprac. G. Herling-Grudziński, Rzym 1947. 
Paryska „Kultura” zajmowała się promowaniem niezależnego polskiego i wschodnioeuropejskiego pisarstwa — „tworzeniem wolnej przestrzeni dla myśli i słowa”. Publikowała także artykuły polemiczne dotyczące drażliwych stosunków narodowościowych na Litwie — Jasienica był ich namiętnym czytelnikiem i komentatorem ${ }^{85}$.

Część polskiej inteligencji z Kresów Wschodnich, która przeszła gułagi i ucieczkę $\mathrm{z}$ „nieludzkiej ziemi” oraz postanowiła pozostać na Zachodzie, należała do grona związanego z bezpowrotnie utraconym wileńskim Uniwersytetem Stefana Batorego. Ich głos bardzo się liczył dla Jasienicy, wszak czuł się cząstką tego endemicznego — jedynego w swoim rodzaju grona. Nie przeszkadzało mu to jednak w żywym reagowaniu na artykuły publikowane $\mathrm{w}$ prasie emigracyjnej. Zdawał sobie zresztą doskonale sprawę z niejednorodności politycznej tego środowiska - wzajemnych antagonizmów i podziałów światopoglądowych. „Emigracja nasza — jak z posiadanych dziś wiadomości sądzimy — bynajmniej wzorem solidarności nie była"86 — pisał już w 1947 roku. Nie ukrywał także, że ma za złe „Londynowi”, iż nie tylko pozwolił ukryć w swoim gronie, ale i publikuje teksty dawnych kolaborantów, z którymi on - żołnierz AK — walczył na Kresach. Mowa była o Józefie Mackiewiczu, znanym mu pracowniku wileńskiej gadzinówki „Goniec Codzienny”, a teraz przede wszystkim autorze Drogi donikad wydanej w 1955 roku $^{87}$ :

Autor powiada we wstępie, że szkice do swej powieści przygotowywał już podczas wojny. Nie tylko szkice. Całe fragmenty, które my, Polacy z Wilna, mieliśmy możność czytać w „Gońcu Wileńskim”, hitlerowskiej gadzinówce, założonej jesienią 1941 roku. Józef Mackiewicz był jej współpracownikiem i filarem. Można było ostatecznie machnąć ręką na jej redaktora naczelnego, Ancerewicza, marnego dziennikarzynę z Białegostoku, którego ludzie z AK przykładnie zastrzelili w kruchcie kościoła św. Katarzyny, przeczytawszy mu przed tym wyrok. Trudniej było przeboleć, że w „Gońcu” produkuje się Józef Mackiewicz, jeden z najlepszych polskich reporterów, autor Buntu rojstów. „Ohyda! Ohyda!”.

W „Gońcu” (w żargonie podziemia zwanym „Podgońcem”) ukazały się liczne fragmenty obecnej Drogi donikad, między innymi opis aresztowania i przesłuchania Pawła, czyli samego Józefa Mackiewicza, którego NKWD razu pewnego zatrzymało na przeciąg godzin czterdziestu i ośmiu. Dobrze pamiętam te rzeczy. Służyłem w Armii Krajowej, miałem przydział do propagandy, więc pilne czytanie szmatławców zaliczało się do moich obowiązków. Pisywało się zresztą o Józefie Mackiewiczu już wtedy w prasie podziemnej. Nie przypuszczałem, że utwory z „Gońca” przyjdzie mi po kilkunastu latach znowu czytać, ale wydrukowane w Londynie - w Londynie, skąd się wtedy otrzymywało rozkazy, spełniane wiernie i ślepo! - i szeroko reklamowane w prasie tamtejszej jako jedyna prawdziwie polska literatura ${ }^{88}$.

Był to tylko wstęp - charakterystyka osoby autora - do szerszej wypowiedzi Jasienicy, wspomnieniu o utraconym świecie wielonarodowych Kresów:

${ }^{85}$ P. Jasienica, Między stotkami, Przegląd Kulturalny 1956 nr 9; przedruk w: tenże, Ślady potyczek, s. 67-72.

${ }^{86}$ Tenże, Warto pogadać, Tygodnik Powszechny $1947 \mathrm{nr} 9$, s. 4.

87 J. Mackiewicz, Droga donikąd, Londyn 1955. „W tymże roku [1955] wyszła jedna z trzech największych powieści Mackiewicza pt. Droga donikąd. Akcja jej toczy się w okresie sowieckiej okupacji Wilna, gdzie w zakończeniu bohater powieści wraz z żoną i kochanką, na jednym koniu jadą po prostu do lasu. Jedna z tych kobiet pyta go: - A dokąd ta droga? A on odpowiada: - Donikąd. Ktoś kiedyś drwiąc mówił, iż myśmy wszyscy wiedzieli dokąd idziemy, a jedynie zdezorientowany Mackiewicz nie wiedział i napisał Drogę donikąd"; Z. Siemaszko, Józef Mackiewicz na tle Rzeczypospolitej wielu narodów, Więź 1991 nr 2, s. 96.

${ }^{88}$ P. Jasienica, Moralne zwtoki szlachcica kresowego, s. 194-195. 
W Drodze donikąd występują przedstawiciele rozmaitych narodowości zamieszkujących Wileńszczyznę (było ich tam, jak wiadomo, siedem, a razem z nielicznymi Niemcami nawet osiem). Są Litwini, Żydzi, Białorusini, Rosjanie, i pół-Rosjanie. Wśród nich jedna grupa wyróżnia się cechami szczególnie nikczemnymi. To są Polacy. Sami tchórze, donosiciele, karierowicze, kanalie i wazeliniarze. W najlepszym razie mięczaki. [...]

Nie ma w tej książce miłości do kraju, ludzi i miasta. Nie widać uroku i piękna Wilna, które wszak nie mają sobie równych.

Mieszkańcy tego kraju przeżyć musieli podczas wojny rzeczy bolesne i ciężkie. Dusze ich ukształtował przecież proces historyczny, który trwał lat przeszło pięćset, od unii Polski z Litwą. A oto w latach 1939-1945 przyszło temu pokoleniu podsumować i zamknąć rachunki. Oczekiwać w tych warunkach, że ludzie ci od razu we wszystkim się zorientują, nie narobią tragicznych błędów - to tyleż znaczy, co domagać się bezpośredniej interwencji sił nadprzyrodzonych. To pokolenie musiało uznać i zapłacić moralną cenę takiego fenomenu dziejowego, że największe dzieła polskiej poezji wiążą się nie z Poznaniem czy Krakowem, lecz z Nowogródkiem i Wilnem - a zachodnia granica obszaru zwarcie zamieszkanego przez Białorusinów przebiega o sto kilkadziesiąt kilometrów na wschód od Warszawy. [...]

Józef Mackiewicz świadomie skłamał, tając przed czytelnikami wybuch najdzikszych szowinizmów, który skłócił ze sobą narody Wileńszczyzny. Nie wspomniał o nienawiści do Polaków, którzy przez stulecia byli w tamtych stronach „rasą panów” i doczekali się niemiłej odpłaty. Nie mógł zresztą powiedzieć prawdy, bo to by wymagało stwierdzenia, że przez cały okres wojny właśnie od sierpnia 1940 do czerwca 1941 roku nie można było na ulicach Wilna głośno mówić po polsku, nie narażając się na przykrości, na pobicie i nawet na śmierć. I że jedynym wyjściem z sytuacji był masowy exodus Polaków do Polski. [...]

Literatura polska zna pisarza, który przebywając na emigracji, przedstawił „kraj lat dziecinnych". Obraz społeczeństwa polskiego na Litwie jest w Panu Tadeuszu nieprawdziwy, wyidealizowany. Prawdziwa jest za to wielka, bezmierna miłość autora do ludzi i kraju.

Książka Józefa Mackiewicza jest od tej przywary romantycznej najzupełniej wolna ${ }^{89}$.

Jasienica proroczo odgadł, że będzie chyba jedynym prawdziwie krytycznym krytykiem powieści Józefa Mackiewicza, pisał:

Nie znam wszystkich recenzji z Drogi donikąd. W tych, które czytałem, nie znalazłem uwag ani polemik na wspomniany temat. Znalazłem zachwyty oraz tezy, że Droga donikąd jest najlepszą powieścią polską napisaną po wojnie ${ }^{90}$.

I rzeczywiście, uniwersytecki kolega Jasienicy Czesław Miłosz, skupił się na pisarskiej formie powieści, uznając Mackiewicza za najlepszego prozaika ukazującego

${ }^{89}$ Tamże, s. 197-199.

90 Tamże. W 2006 roku Jacek Trznadel napisał: „Jeśli się nie mylę, w PRL ukazało się tylko jedno omówienie jego [Mackiewicza] prozy, Drogi donikąd, Paweł Jasienica ogłosił paszkwil pod unicestwiającym tytułem: Moralne zwłoki szlachcica kresowego. Zadziwiające, że pisał to były partyzant, walczący dopiero co z sowiecką żandarmerią, w grupie Łupaszki, cudem ocalony od wyroku śmierci. W jednej ze swoich publikacji Mackiewicz nawiązał krytycznie do tego tekstu Jasienicy. Wspomniał o współpracy Jasienicy z propagandową komunistyczną Rozgłośnią «Kraj». Szedł daleko w swej nieufności. Ale czy wystąpienie Jasienicy nie było także podobne do tej fali krytyki Mackiewicza, która miała się rozlać i na Zachodzie $\mathrm{z}$ «arcypolskich» pozycji? Z tym że Jasienica doskonale wiedział, że proza krytykująca komunizm jest w kraju całkowicie zakazana"; zob.: J. Trznadel, Historia $i$ wojna w prozie Mackiewicza, [w:] Józef Mackiewicz i krytycy, s. 610 . 
realia życia codziennego ${ }^{91}$. Tak było w roku 1955, jednakże w 1989 Miłosz podążył śladem wojennej przeszłości Mackiewicza, szukając źródeł tak różnych i wzajemnie się wykluczających opinii o autorze Drogi donikąd. Miłosz próbował dokonać rzeczy niemożliwej, uszanować Jasienicę, człowieka prawego i nieustraszonego, walczącego do końca i obronić Mackiewicza, jego wybory życiowe i pisarstwo. Jednocześnie Miłosz był jedynym, który broniąc Mackiewicza rozumiał zarazem intencje Jasienicy:

Moralne oburzenie Beynara jest szczere i powtarzając za Jądrem ciemności Conrada „ohyda! ohyda!”, na pewno wyraża uczucia wielu swoich rówieśników [z okresu okupacji]. Wglądnąwszy jednak bliżej w jego artykuł, nie znajdzie się w nim wiele poza stanem uczuciowym ${ }^{92}$.

Ostatecznie Miłosz widział w powieści Mackiewicza to, co Jasienica tak bardzo chciałby zobaczyć jako kresowiak: „Wbrew posądzeniom Jasienicy jest to książka miłości do zdeptanej ojczyzny" 93 .

Inni adherenci Mackiewicza już nie byli tak pobłażliwi. W wolnej Polsce krytycy literaccy oskarżyli Jasienicę o napisanie paszkwilu, uznali, że należał on do chóru, który publicznie lżył emigracyjnego pisarza i to na równi z Józefem Cyrankiewiczem oraz publicystami „Trybuny Ludu” - tym samym zrównali polemiczne eseje Jasienicy $\mathrm{z}$ językiem propagandy ${ }^{94}$. Pojawiły się nawet głosy oskarżające Jasienicę o współpracę z PRL-em ${ }^{95}$.

Na marginesie debaty o Drodze donikad, warto przypomnieć jeszcze artykuł Jasienicy z 1947 roku. Na łamach „Tygodnika Powszechnego” przyznał, iż redakcja otrzymała książkę Instytutu Literackiego z Rzymu pod tytułem W oczach pisarzy. Wybór

${ }^{91}$ Cz. Miłosz, „Polacy z Kresów”: Proszę uszanować Wilnianina, Kultura 1955 nr 12(98), s. $130-133$.

92 Tenże, Koniec Wielkiego Xięstwa (O Józefie Mackiewiczu), Kultura 1989 nr 5(500), s. 102-120; przedruk w: Józef Mackiewicz i krytycy, s. 459.

93 Tenże, Gtos wiernego czytelnika, Archiwum Emigracji. Studia - Szkice - Dokumenty 2003 z. 5/6, s. 157-158. Do krytyków Mackiewicza - ale raczej z wrodzonej przekory niż literackich lub politycznych animozji — należał Stefan Kisielewski, który w wywiadzie udzielonym Jerzemu Giedroyciowi wyznał: „Mam też wobec was [,Kultury”] pewien zarzut personalny: że drukujecie Józefa Mackiewicza, który zarówno ze względu na swą okupacyjną przeszłość jak i na sprzeczne z polską racją stanu poglądy, moim zdaniem, drukowany u was być nie powinien"; zob.: Rozmowa ze Stefanem Kisielewskim, Kultura 1957 nr 6(116), s. 35. Później Kisielewski nieznacznie wycofał się z tych słów; zob.: S. Kisielewski, Abecadło Kisiela. Testament Kisiela, Warszawa 2011, s. 79.

${ }^{94}$ O Jasienicy, w kontekście jego ataków, jako części propagandy komunistycznej w Polsce pisali: Jacek Trznadel, Marek Zybura, Maria Zadencka, Włodzimierz Bolecki, Grzegorz Eberhardt. Krzysztof Masłoń pisał: „Zdecydowany protest budzą z kolei jego [Jasienicy] kompletnie nieodpowiedzialne, za to wybitnie koniunkturalne, ataki na Józefa Mackiewicza, tym bardziej niestosowne, że w tamtych warunkach o jakiejkolwiek polemice mowy być nie mogło. Obaj adwersarze pisali więc do różnych odbiorców, krajowych i emigracyjnych. W związku z tym opinie ulegać mogły jedynie zaostrzeniu i nie dziwi fakt, że Józef Mackiewicz nigdy nie wybaczył Jasienicy artykułu Moralne zwłoki szlachcica kresowego"; zob.: K. Masłoń, Beynar, kolega Burtaja, Rzeczpospolita 13.11.2009.

${ }^{95}$ Zob. wywiad Marty Kwaśnickiej z Grzegorzem Eberhardtem o jego najnowszej książce, Pisarz dla dorostych. Opowieść o Józefie Mackiewiczu. Autor książki odpowiadając na pytanie dotyczące adwersarzy Józefa Mackiewicza użył sformułowania, iż „Jasienica współpracował z PRL, wiemy to, i dlatego bez skrupułów umieściłem go we wspomnianym rozdziale"; Pisarz zakazany, rozmowa M. Kwaśnickiej z G. Eberhardtem, [on-line]. [Dostęp: marzec 2008]. Dostępny w WWW: http://www.polskieradio.pl/24/289/Artykul/176171,Pisarz-zakazany. 
opowieści wojennych (1939-1945). Jasienicę zainteresowało opowiadanie Ponary Baza, podpisane pseudonimem J. M. — nie ujawnia tożsamości autora, nie daje też do zrozumienia, czy wie kto się za nim kryje, ale niemożliwe by nie wiedział, że jest nim właśnie Józef Mackiewicz. Według Jasienicy był to pierwszy artykuł dotykający tematu tragicznej strony okupacji Wilna - eksterminacji ludności żydowskiej, dokonanej na lesistych terenach nieopodal Wilna przez nacjonalistów litewskich pod nadzorem władz niemieckich. „I w Polsce mało kto — poza repatriantami — wie co oznacza słowo Ponary. A było to największe bodaj na dawnych kresach miejsce straceń" — pisal $^{96}$. Ale i tym razem Jasienica miał pretensje do Mackiewicza o pominięcie w opowiadaniu martyrologii polskiej:

Autor opowiadania Ponary - Baza był przypadkowo świadkiem wymordowania na tamtejszej stacyjce całego transportu Żydów, którzy rzucili się do ucieczki. Opisał co widział i przypomniał światu słowo „Ponary”. Nie rozumiem natomiast, czemu pominął milczeniem jeszcze jedną rzecz. Oto w Ponarach oprócz Żydów leżą tysiące Polaków. Razem. W tych samych dołach. [...] Czemu o tym wszystkim zapominamy? ${ }^{97}$

Pół roku po śmierci Jasienicy w „Wiadomościach” londyńskich ukazał się artykuł Józefa Mackiewicza pod tytułem Casus Paweł Jasienica ${ }^{98}$. Autor nawiązywał w nim do wcześniejszych wypowiedzi na temat swojego adwersarza, nazywając go pisarzem o ,elastycznym piórze”, czyli twórcy dyspozycyjnego wobec władz komunistycznych, czy wręcz służącego interesom dyktatury proletariatu.

Grzechów Jasienicy w oczach Mackiewicza było zresztą więcej, wymienia następujące:

1) rozbicie działalności charytatywnej Kościoła poprzez członkostwo w zeświecczonym Caritasie;

2) praca w warszawskiej Rozgłośni „Kraj”, co samo przez się rozumiano jako służenie aparatowi propagandy komunistycznej, tym bardziej, że głosił tam poglądy;

3) o ,anachronizmie” przynależności Wilna do Rzeczypospolitej (tu Mackiewicz powołuje się na endecką „Myśl Polską” (wydawaną również w Londynie), w której Jasienicy zarzuca się poglądy antynarodowe: „przedstawienie rozbiorów Katarzyny jako postępu, a zmowy Hitlera i Stalina jako realizacji polskiej racji stanu...,"99;

4) ,Jasienica napisał kilka książek o tematyce historycznej, w tej liczbie o Jagiellonach, zgodnie z doktryną historyczną wytyczoną w PRL. Że np. błąd Jagiellonów polegał na tym iż parli na wschód, przeciw Moskwie, zamiast zwrócić się na zachód, przeciw Niemcom. Że np. «czerwoni» w powstaniu r. 1863 mieli rację, a nie «biali» itp. Jego poglądy osobiste mogły się pokrywać z obowiązującą doktryną historyczną. Nie powinniśmy jednak oszukiwać siebie, że mógł napisać odwrotnie. Tzn. napisać by mógł, ale wydać nie. Książki wydawane są w PRL przez wydawnictwa partii komunistycznej. Innych tam nie ma. Książki sprzeczne z planem kulturalnym nie są, i nie mogą być wydawane w ustroju komunistycznym. [...] «pisarz polski w kraju», z talentem czy bez, jest de facto pracownikiem komunistycznej polityki kulturalnej, albo przestaje być pisarzem. Gdyż w każdej chwili może być zwolniony z pracy literackiej, jak każdy pracownik nie odpowiadający wymogom pracodawcy. Jasienica, jeżeli chciał

\footnotetext{
${ }^{96}$ [P. Jasienica] (jas.), Ponary, Tygodnik Powszechny 1947 nr 41, s. 12.

${ }^{97}$ Tamże.

${ }^{98}$ J. Mackiewicz, Casus Pawet Jasienica, Wiadomości 1971 nr 3(1294), s. 2.

${ }^{99}$ Tamże.
} 
uprawiać zawód pisarza, musiał się podporządkować obowiązującym rygorom. Chyba żeby próbował emigrować. Jasienica nie próbował emigrować"100;

5) umarł śmiercią naturalną, „na wolności, bez procesu i bez więzienia”, był więc pisarzem PRL-owskim, który tylko czasowo (pod koniec życia) stracił przychylność partii, bo w innym wypadku, gdyby rzeczywiście był prawdziwie opozycyjnym pisarzem, np. w czasach stalinowskich, straciłby życie, wcześniej uczestnicząc w procesie pokazowym;

6) „to, co dał do zrozumienia Gomułka w swojej wypowiedzi o Jasienicy, to wiedział co mówił" (autor powołuje się na swój wcześniejszy list do redakcji w tej sprawie).

Już w lutym, zaledwie trzy tygodnie później ukazały się komentarze czytelników do artykułu Mackiewicza — w dziale „Korespondencji” umieszczono m.in. list Alicji Lisieckiej:

Łatwo, żyjąc od lat w Monachium, krytykować 32 miliony Polaków „,nie próbujących emigrować" i walczących o prawo do życia w swoim kraju. Za tę walkę „,kolaboranci” z komunistycznych stoczni i fabryk, komunistycznych piekarni i sklepów, zapłacili ostatnio wysoką cenę. O mało co nie zapłacił jej swego czasu Paweł Jasienica, skazany na karę śmierci za udział w partyzantce akowskiej. Wyreklamowany $\mathrm{z}$ więzienia przez powojenny Związek Pisarzy, zobowiązał się do rezygnacji z druku w „Tygodniku Powszechnym" na rzecz paxowskiego pisma, z którego zresztą wkrótce postarał się odejść. To były owe „,warunki”, na których mocy nie spadła wówczas głowa pisarza, usuwanego także potem, już w r. 1968, ze Związku Literatów i zmuszonego do ukrywania się.

Gomułka nie wiedział co mówi, ale wiedział co robi Bezpieczeństwo, podsuwając mu fałszywe materiały, mające na celu skompromitowanie autora książek, które często - wbrew cenzurze - jak np. Polska Jagiellonów trafiły pod strzechy. Jako redaktorka „Nowej Kultury” w latach 1960-1962, pamiętam dobrze zarzut dotyczący druku przez nasze pismo odcinków rzekomo „obcej duchowo socjalizmu” Polski Jagiellonów Pawła Jasienicy.

Łatwo pouczać i ganić polskich robotników. Trudniej zarobić życiem pełnym udręki, w grozie przed śmiercią cywilną i więzieniem, na piękną, patriotyczną kartę nauczyciela historii Polski Pawła Jasienicy ${ }^{101}$.

Alicja Lisiecka wiedziała co pisze, jak sama przyznała była redaktorką „Nowej Kultury” — ale nie tylko - współpracowała z szeregiem pism krajowych: „Polityką”, „Życiem Literackim”, „Twórczością”, była doktorem habilitowanym, pracownikiem Instytutu Badań Literackich PAN — na fali czystek po Marcu '68 wyemigrowała z kraju.

W obronie dobrego imienia Jasienicy stanęli także emigracyjni historycy, a wśród nich: Józef Garliński, Piotr Wandycz i Marian Kukiel. Józef Garliński, współpracownik Instytutu Hoovera przy Uniwersytecie Stanforda w Kalifornii (gdzie gromadził archiwalia poświadczające polski czyn zbrojny na Zachodzie), zwrócił uwagę na pewien paradoks oskarżeń Mackiewicza wobec Jasienicy. Otóż Gomułka — „niewątpliwy komunista i partner Sowietów”, o którym Mackiewicz mógłby napisać najohydniejsze rzeczy, w momencie nagonki na Jasienicę w 1968 roku stał się nagle godnym wiary świadkiem oskarżenia Jasienicy. Przypominamy raz jeszcze, co Mackiewicz wówczas pisał: „W moim przekonaniu to, co dał do zrozumienia Gomułka w swojej wypowiedzi o Jasienicy, to wiedział co mówił”. Garliński puentował ten zabieg następująco:

Niestety w sprawach, które wymagają obiektywizmu, zbyt jaskrawo stosuje się zasadę

\footnotetext{
100 Tamże.

${ }^{101}$ A. Lisiecka, Do redakcji „Wiadomości”: O Jasienicy, Wiadomości 1971 nr 6(1297), s. 6.
} 
dwóch nierównych miar, i to u nas, na emigracji, na wolnym Zachodzie, gdzie nie ma żadnego usprawiedliwienia dla takich chwytów ${ }^{102}$.

Poza tym jeżeli obrońcy Mackiewicza zarzucali Jasienicy współpracę z Cyrankiewiczem - bo obaj krytykowali emigracyjnego pisarza - dlaczego podobny zarzut nie spotkał Mackiewicza, ewidentnie stojącego w jednym szeregu z Gomułką przeciw Jasienicy?

Najmocniej chyba jednak zabrzmiał dwugłos Mariana Kukiela i Lidii Ciołkoszowej, którzy na zaproszenie redakcji „Wiadomości” umieścili swoje artykuły, będące faktycznie rozszerzonymi wersjami przemówień ku czci pisarza, wygłoszonymi wcześniej na wieczorach ku jego pamięci. Marian Kukiel uznał pisarstwo Jasienicy — gdy drętwa mowa opanowywała polską publicystykę i historiografię w czasach stalinowskich i później — za prawdziwą kąpiel w polskości i polszczyźnie.

Był to czas, gdy nauki historyczne w Kraju były w niewoli, na prokrustowym łożu okaleczone, półmartwe, odczłowieczone... - pisał Kukiel. - W te lata niewoli i niewolnictwa zaczęły się ukazywać owe szkice Jasienicy. Szkice z zamierzchłej przeszłości. A takim tchnące umiłowaniem i tej przeszłości i tych ludzi, co żyli przed półtora tysiącem lat czy tylko tysiącleciem, że czytelnik skłonny był z Wyspiańskim wołać na tego, kto wie co znaczy polska mowa i oczy kryje ze wstydu: ,przybywaj tu — odżyjesz słowa łaską"103.

Marian Kukiel kończy artykuł żalem, żalem żołnierza emigranta: „Ze smutkiem myślę, że nie było mi dane ręki mu uścisnąć i pomówić o Polsce walczącej na Zachodzie" ${ }^{104}$. Dalej Kukiel - nie tylko historyk, ale przecież bliski współpracownik Władysława Sikorskiego i dowódca 1. Korpusu Polskiego w Wielkiej Brytanii — odnosi się do preferencji politycznych braci Mackiewiczów w czasie wojny; znał Stanisława Cata-Mackiewicza, którego poglądy, podobnie jak Józefa, mieściły w sobie możliwość jakiegoś ułożenia relacji lub nawet współpracy z Trzecią Rzeszą. Zarzucił mu, iż był w roku 1940, kiedy Francja kapitulowała, przeciwnikiem ucieczki Wojska Polskiego na Wyspy Brytyjskie i dalszej tym samym walki. Wierzył w pośrednictwo Pétaina w rozmowach z Hitlerem i wypracowania dla Polaków nowego modus vivendi z okupantem ${ }^{105}$.

Jak bliskie były to poglądy Józefowi Mackiewiczowi, niech świadczy fakt, że jeszcze w 1944 roku, prawie że w przeddzień wybuchu powstania warszawskiego, pisarz chciał redagować $\mathrm{w}$ stolicy pismo pod patronatem niemieckim o charakterze antysowieckim. Jak wspominał Miłosz:

Mackiewicz po przyjeździe do Warszawy [w 1944] wyraził życzenie spotkania się ze mną i z Januszem Minkiewiczem. Odbyliśmy długą rozmowę. Z jego strony było to powtarzane na różne sposoby pytanie ,jak to jest możliwe?”. Więc teraz, kiedy jasne dla każdego, że Alianci są daleko, nic? Żadnej próby dogadania się, choćby w ostatnim momencie, z przegrywającymi Niemcami, skłonnymi już do ustępstw? Teraz przecie można by było wydawać pismo, żeby mówić głośno prawdę o okupacji sowieckiej, tłumioną przez polskie podziemie na usługach Londynu, a pośrednio Moskwy. Słuchaliśmy go z niedowierzaniem, jak się słucha człowieka niespełna rozumu. I wyśmialiśmy go. Powiedzieliśmy mu, że nie ma żadnego rozeznania w tutejszych nastrojach, że nikt

102 J. Garliński, Do redaktora „Wiadomości”: W zwiazku z listem Tomasza Rzyskiego, Wiadomości $1971 \mathrm{nr}$ 7(1298), s. 6.

${ }^{103}$ M. Kukiel, Jasienica w historiografii polskiej, Wiadomości 1971 nr 10(1301), s. 2.

104 Tamże.

${ }^{105}$ Tamże. 
by $\mathrm{z}$ takim pismem nie współpracował, że kolaborantom [...] nikt nie podaje ręki, a on, gdyby zaczął wydawać takie pismo, zostałby napiętnowany jako zdrajca. Mackiewicz nic nam nie powiedział o gazetce „Alarm”, której trzy numery podobno wydali wiosną 1944 we dwójkę z żoną ${ }^{106}$.

Lidia Ciołkoszowa w artykule zatytułowanym Pisarstwo Pawła Jasienicy zwróciła uwagę na absurdalność zarzutów historiozoficznych Józefa Mackiewicza, między innymi zarzutu dotyczącego poglądów Jasienicy na powstanie styczniowe; Jasienica nigdy nie ukrywał, że dla niego to „czerwoni”, a nie „,biali” mieli rację forsując reformy uwłaszczeniowe w Królestwie Polskim, co według Mackiewicza było przykładem zbieżności jego poglądów z obowiązującą w PRL-u doktryną historyczną. W odpowiedzi Ciołkoszowa pisała:

Gdyby więc dziś żyli Bolesław Limanowski, Józef Grabiec i Józef Piłsudski, którzy w swoich pracach o powstaniu styczniowym - mówiąc słowami Mackiewicza — uważali również że „,czerwoni”, a nie „,biali” mieli rację, musieliby być przez Mackiewicza oskarżeni o to że piszą ,,zgodnie z doktryną historyczną wytyczoną w PRL" ${ }^{107}$.

Zwróciła też uwagę na paradoks oskarżeń wysuwanych wobec Jasienicy zarówno tych głoszonych przez prawicę emigracyjną, jak i lewicę komunistyczną w kraju. Po ukazaniu się Polski Jagiellonów, zaatakowały go dwie protagonistki materializmu historycznego: Celina Bobińska i Ewa Maleczyńska. Oskarżyły one Jasienicę o szerzenie tendencyjnych tez historiografii burżuazyjnej i sugerowanie czytelnikowi nacjonalistyczno-polskiego punktu widzenia. W zestawieniu z poglądami Józefa Mackiewicza, głoszącymi dokładnie coś odwrotnego, mamy następującą konkluzję pani Lidii Ciołkosz:

Myślę że Józef Mackiewicz, który twierdzi, jakoby Jasienica pisał książki ,zgodnie z doktryną historyczną wytyczoną w PRL” i p. Maleczyńska, która twierdzi, że Jasienica wypowiada ,tendencyjne tezy historiografii burżuazyjnej” są à rebours takimi samymi umysłowościami ${ }^{108}$.

Piotr Wandycz, który był wówczas wykładowcą historii Europy Środkowo-Wschodniej na Yale University, wystosował list do londyńskich „Wiadomości”, w którym także odniósł się do artykułu Józefa Mackiwewicza:

Pawła Jasienicę widziałem dwa razy w życiu, i polemikę na temat jego postawy polityczno-moralnej pozostawiam osobom lepiej zorientowanym i bardziej kompetentnym ode mnie. Chciałbym natomiast powiedzieć parę słów o Jasienicy jako historyku. Mackiewicz w dość lekceważący sposób pisze o „kilku książkach o tematyce historycznej” pióra Jasienicy, napisanych „,zgodnie z doktryną historyczną wytyczoną w PRL”. Następnie przeprowadza sylogizm, który da się streścić następująco: książki wychodzące w PRL nie mogą być sprzeczne z komunistyczną polityką kulturalną. Jasienica wydawał książki w PRL — ergo Jasienica był komunistycznym pisarzem. Postawienie sprawy w ten sposób, typowo czarno-biały, nie pozwala w ogóle na zobaczenie bogatej gamy odcieni istniejącej w historiografii krajowej. Jest to dość prymitywny schemat, który pozornie wygląda przekonywająco, ale jest w istocie daleki od życia i skomplikowanej rzeczywistości ${ }^{109}$.

${ }^{06}$ Cz. Miłosz, Koniec Wielkiego Xięstwa (o Józefie Mackiewiczu), s. 467-468.

${ }^{107}$ L. Ciołkoszowa, Pisarstwo Pawła Jasienicy, Wiadomości 1971 nr 10(1301), s. 2.

${ }^{108}$ Tamże.

109 P. Wandycz, Do redaktora „Wiadomości”: Jeszcze o Jasienicy, Wiadomości 1971 nr 20(1311), s. 6. 
Podobnych sylogizmów w wywodach Mackiewicza i jego obrońców było zresztą więcej. Podczas polemiki z Janem Nowakiem Jeziorańskim - co przypomina Grzegorz Eberhardt, biograf Mackiewicza — Jeziorański wspominał:

Pytany [Mackiewicz] o narodowość odpowiadał: jestem antykomunistą. Mnie osobiście takie samookreślenie nie wystarczało. Hitler też był antykomunistą ${ }^{110}$.

Grzegorz Eberhardt puentuje, odpowiadając za Mackiewicza:

Stwierdzenie, jakoby Hitler był antykomunistą, kompromituje intelektualnie Nowaka. Gdyby Hitler faktycznie był antykomunistą, wygrałby wojnę ze Związkiem Sowieckim! Hitler był, jak Stalin, socjalistą. Tak więc, towarzysze jedynie starali się (za pomocą wojny akurat) o powiększenie areałów swych królestw ${ }^{111}$.

Wywód godny autora. W takiej sytuacji można by zapytać: gdzie należałoby umieścić Józefa Piłsudskiego — socjalistę? Jako zwycięzca bolszewików z wojny 1920 roku przysługiwałoby mu, według kryteriów Mackiewicza, także miano antykomunisty i to chyba jedyny taki wypadek. A jednak nie! Grzegorz Eberhardt musi przecież znać artykuł Józefa Mackiewicza zatytułowany Nasza strona medalu z londyńskich „Wiadomości"112, w którym oskarżał Józefa Piłsudskiego o świadome unikanie decydującego starcia z bolszewikami, co doprowadziło w konsekwencji do ich zwycięstwa w wojnie domowej. Oskarżanie Piłsudskiego o grzech zaniechania w rozprawieniu się ze światowym bolszewizmem jest też motywem Lewej wolnej — powieści Mackiewicza z 1965 roku $^{113}$ (o stosunku Jasienicy do tych poglądów — w dalszej części artykułu).

Walka na sylogizmy jest zresztą obosieczna: jeśli Mackiewicz uważa, że Jasienica był komunistą, bo publikował w Polsce pod władzą komunistyczną, to tym samym Mackiewicz podczas wojny i okupacji był tubą najohydniejszej propagandy goebbelsowskiej, gdyż pisał artykuły w „gadzinówce” niemieckiej; firmował tym samym eksterminację Słowian, Żydów, Romów i inne narody europejskie oraz wszystkie fabryki śmierci założone przez Rzeszę Niemiecką i wszelkie zbrodnie wojenne. Do takich absurdów doprowadza widzenie świata tylko w czarno-białych kolorach.

Spór rozgorzał na nowo po śmierci Jasienicy, a później i Józefa Mackiewicza, wraz z mozolnym „odtwarzaniem” dorobku literackiego emigracyjnego pisarza; pojawili się także jego obrońcy (i dobrze). Szkoda tylko, że podobnie jak Mackiewicz, świat widzieli jedynie dwukolorowo. Poza tym, na postać Jasienicy patrzy się, w tym wypadku, także przez pryzmat innych adwersarzy Mackiewicza — głównie politycznych, takich jak: Stefan Korboński, gen. Tadeusz Pełczyński, Jan Nowak Jeziorański, Józef Garliński, Andrzej Pomian... jak widać, ludzi związanych głównie z Polskim Państwem Podziemnym i Armią Krajową. I nie może to dziwić, skoro Józef Mackiewicz był jawnym krytykiem układu Sikorski-Majski, a o operacji „Ostra Brama”, gdzie wykrwawiło się wileńskie i nowogródzkie AK w walce o wyzwolenie Wilna, pisał:

Gdy z perspektywy patrzę na to co się stało, dziś wstydzę się i żałuję, ale nie tego, że nie znalazłem się po stronie tych, którzy w roku 1944 Wilno dla bolszewików pomagali

\footnotetext{
${ }^{110}$ J. Nowak Jeziorański, Polska z oddali, Kraków 1992, s. 217.

111 G. Eberhardt, Pisarz dla dorostych. Opowieść o Józefie Mackiewiczu, Wrocław 2008, s. 544.

112 J. Mackiewicz, Nasza strona medalu, Wiadomości 1956 nr 19(527), s. 3.

${ }^{113}$ Tenże, Lewa wolna, Londyn 1965.
} 
zdobywać, lecz tego, że nie znalazłem się po stronie tamtych, którzy go przed bolszewikami bronili... 114

lub:

Nasze cierpiętnictwo i nasza martyrologia w zestawieniu na przykład z martyrologią Żydów pod reżimem hitlerowskim, zdawała się lekkim bluffem ${ }^{115}$.

Na koniec warto przypomnieć, że Mackiewicz dopominał się od Polaków by pisali na temat cierpień ludności niemieckiej podczas wojny ${ }^{116}$.

Co mogli myśleć żołnierze pułkownika „Wilka” Krzyżanowskiego — walczący raz z jednym, raz z drugim okupantem - czytając takie słowa, słowa pisane przez człowieka, który ani razu w tej wojnie nie chwycił za broń? Przed bolszewikami uciekł do Kowna, po powrocie do Wilna, pod okupacją niemiecką oddał swoje pióro propagandzie okupacyjnej, następnie, wraz ze zbliżającym się frontem sowieckim zbiegł do Warszawy (na paszporcie litewskim), gdzie znowu, w przeddzień wybuchu powstania, chciał służyć Niemcom. Nie czekając na walki w stolicy, uciekł do Krakowa, stamtąd do Pragi, potem Wiednia i ostatecznie do Włoch. Iście patriotyczne działanie. I zrobił to człowiek, który z drugiej strony, za pozwoleniem władz AK, widział i opisał Katyń.

Może rację ma Włodzimierz Bolecki, który uważa, że

zawsze cenili i bronili Mackiewicza pisarze, atakowali go natomiast byli oficerowie, którzy na emigracji stali się politykami. Niewielu ich było, ale jeśli chodzi o twórczość Mackiewicza, nigdy tak niewielu nie wyrządziło tak wiele szkody ${ }^{117}$.

Jasienica był i oficerem AK, i pisarzem. Nie był tylko na emigracji.

W odniesieniu do artykułu Moralne zwłoki szlachcica kresowego Bolecki pisze:

Droga donikąd doczekała się także recenzji w kraju — jej autorem był Paweł Jasienica, ale lektura tego tekstu nie jest przyjemna.

Jasienica za kilka lat stanie się jednym z najważniejszych polskich pisarzy współczesnych: autorem esejów historycznych będących odtrutką na brednie o dziejach Polski sporządzone przez specjalistów od wulgaryzowania przeszłości. W latach sześćdziesiątych będzie jednym z moralnych autorytetów młodej inteligencji, za co — po marcu 1968 r. - zostanie w ohydny sposób zaatakowany przez ówczesnego genseka. Atak ten - jak wiadomo - Paweł Jasienica przypłacił życiem. Jednak czytając napisaną w 1955 r. recenzję z Drogi donikąd trzeba zapomnieć o Pawle Jasienicy z roku 1968. W 1955 roku Paweł Jasienica był jeszcze współpracownikiem prasy PAX-owskiej.

Kulisy tego tekstu nie są dla mnie do końca jasne, chociaż jest oczywiste, że decydując się na napisanie recenzji z powieści Mackiewicza, Jasienica nie powodował się jedynie odruchem miłośnika książek. Z tekstu recenzji wynika jednoznacznie, że była to dla jej autora sprawa osobista: w 1941 r. Jasienica (ówczesne nazwisko Leon Lech Beynar) jako żołnierz AK ,przydzielony do propagandy” czytał w „Gońcu Codzien-

${ }^{114}$ Tenże, „List do Redakcji”, Kultura 1957 nr 7-8(117-118), s. 224. „W drugiej połowie roku 1944 moc ludzi nadawałaby się do zastrzelenia w Wilnie. Chociażby Czerniachowski i wszystkie armie jego «3-go białoruskiego frontu». Tymczasem przeciwnie, wiemy, że im pomagało się przecie w zdobywaniu Wilna, a później przyjmowano zaproszenie na wspólny bankiet. Oficjalna wersja stwierdzała, że: «sielanka trwała długo», bo potem przywódcy AK zostali aresztowani. Tym samym jednak potwierdza się fakt, że taka sielanka była"; tenże, O pewnej ostatniej próbie i o zastrzelonym Bujnickim, Kultura 1954 nr 11(85), s. 81-95.

${ }^{115}$ Cyt. za: W. Bolecki, Ptasznik z Wilna, s. 230.

${ }^{116}$ P. Jasienica, Czyżby księga święta?, Przegląd Kulturalny 1956 nr 17; przedruk w: tenże, Ślady potyczek, s. 65.

${ }^{117}$ W. Bolecki, Ptasznik z Wilna, s. 296. 
nym” fragmenty Drogi donikąd. Z innych źródeł wiadomo, że w grudniu 1941 r. napisał nawet artykuł przeciwko Mackiewiczowi ${ }^{118}$.

Zarzuty wobec Jasienicy, jako przeciwnika Mackiewicza, można streścić do jednego podstawowego paradygmatu - Jasienicowy atak na Mackiewicza był albo wespół, albo za zgodą władz komunistycznych — innego wyjścia nie było i samo w sobie było to niegodne Jasienicy. Tym samym obrońcy Mackiewicza — posługując się tym swoistym wzorem — wykluczają możliwość samodzielnego i niezależnego myślenia i wyrażania myśli w Polsce. Słowem - tylko poglądy przeciwne komunistom były faktycznie niezależne, każde inne były tylko potwierdzeniem przynależności do ideologii marksistowskiej. Koronnym tego przykładem był fakt — na który powołują się wszyscy zwolennicy Mackiewicza — że artykuł Jasienicy Moralne zwłoki szlachcica kresowego z 1955 roku, wpisuje się, lub lepiej, jest częścią ataku na emigracyjnego pisarza dokonanego jedenaście lat później — w 1966 roku — przez Józefa Cyrankiewicza. Cyrankiewicz podczas sesji naukowej na Wawelu określił Mackiewicza znikomą częścią polskiej emigracji, która głosi nihilistyczne tezy. „Tezy te wyrażają chęć zatrzymania zegara historii nawet przez samounicestwienie”. „«Lepiej zginąć na wojnie termojądrowej, niż żyć w ustroju komunistycznym» — tak to wyraża emigracyjny pisarz Józef Mackiewicz w jednej ze swoich książek" — głosił Cyrankiewicz na Wawelu ${ }^{119}$.

Czy Cyrankiewicz czytał artykuł Jasienicy sprzed jedenastu lat? Może tak, ale na pewno go nie pamiętał, wykorzystałby przecież niechybnie tekst do swojej argumentacji. Zresztą, jak widać Cyrankiewicza nie interesowały animozje wewnętrzne emigracji ani kłótnie dawnych kresowiaków. On stał na stanowisku Polski Ludowej.

W takim razie czy Jasienica pisał pod dyktando propagandy komunistycznej, czy, jak twierdzi Marek Zybura, nawet lżył emigracyjnego pisarza? ${ }^{120}$ Sam fakt pisania przeciwko kolaborantowi wojennemu na ponad dekadę przed komunistycznym premierem i to w sprawach całkowicie odmiennych, nie może być argumentem w oskarżeniu o współpracę z PRL-em, takie insynuacje są wręcz manipulacją faktami. Jasienica zarzucał Mackiewiczowi — świetnemu reporterowi i pisarzowi, jak twierdził — że oddał swoje pióro niemieckiemu okupantowi i w Drodze donikad nieuczciwie przedstawił społeczeństwo polskie. Co wydaje się, rozumiał jedynie inny wilnianin, Czesław Miłosz - o czym wspominam wyżej. Stawianie Jasienicy i Cyrankiewicza w jednym rzędzie przypomina działanie Stalina, który oskarżył gen. Sikorskiego o współpracę z Hitlerem, bo jeden i drugi zwrócili się do Międzynarodowego Czerwonego Krzyża o wysłanie ekspertów do Katynia. Jak pamiętamy, oskarżenie to — haniebne — posłużyło do zerwania stosunków dyplomatycznych ZSRR z polskim rządem na uchodźstwie. A jeśli ktoś naprawdę chce znać stosunek Jasienicy do Cyrankiewicza i całej nowej władzy ludowej, powinien sięgnąć po jego artykuły prasowe z „Tygodnika Powszechnego". Jest ich naprawdę wiele i żaden z nich nie budzi wątpliwości, co do faktycznych poglądów Jasienicy na ówczesny reżim ${ }^{121}$.

118 Tamże, s. 776-777.

${ }^{119}$ Tamże, s. 31; M. Fik, Kultura polska po Jatcie. Kronika lat 1944-1981, Londyn 1989, s. 392.

${ }^{120}$ M. Zybura, Józef Mackiewicz i krytycy, s. 679.

${ }^{121}$ Zob. m.in.: Czy dobrze rozumiem? (1946 nr 22, s. 8); Tradycja AK (1946 nr 44, s. 12); Honor (1946 nr 13, s. 3); Obrońca prawdy (1946 nr 10, s. 8, podpisany: pej.); Karty na stót (1946 nr 14, s. 8, podpisany: pej.); „Przyjacielu - przesiądź się niżej” (1946 nr 18, s, 8, podpisany: p. jas.); Stwierdzam fakty (1946 nr 30, s. 8); „Życzliwość” (1947 nr 26, s. 2); Wskazuje szczegóty (1947 nr 30, s. 8, podpisany: jas.); Po prostu niedobrze się robi (1948 nr 27, s. 12, podpisany: jas.). 
Jasienica wyrażał własne sądy w sposób jasny i bezpośredni niezależnie od koniunktury politycznej: jeśli wierzył, że zmiany ustrojowe po 1945 roku przyniosą masie młodzieży polskiej — szczególnie tej biedniejszej, znanej mu z czasów sanacji — szansę lepszej i łatwiejszej w dostępie edukacji, to naprawdę w to wierzył. Stąd między innymi artykuły o problemach oświaty publikowane w „Tygodniku Powszechnym” w pierwszych latach po wojnie ${ }^{122}$. Jeśli w kwestiach historiozoficznych, uważał że „czerwoni”, a nie ,biali” mieli rację w powstaniu styczniowym - stały punkt ataku na Jasienicę - to rzeczywiście tak myślał, i nie można przecież traktować „czerwonych” z powstania styczniowego w kategoriach „,czerwonych” z Polski Ludowej, bo to rzeczywiście kompromituje obrońców Mackiewicza (jak i jego samego). Podobnie jest $\mathrm{z}$ innymi poglądami historiozoficznymi.

Zarzut wobec Jasienicy, że nie przysługuje mu miano „wiernego tradycjom filareckim" - jakie nadała mu na emigracji Społeczność Akademicka USB — bo nie zginął w kazamatach UB, lecz zmarł śmiercią naturalną — nie jest wart komentarza ${ }^{123}$.

W artykule Józefa Mackiewicza Casus Pawet Jasienica pojawiło się także oskarżenie o współpracę autora Polski Jagiellonów z PAX-em Bolesława Piaseckiego i rozbicie Caritasu. Odpowiedź na podobne zarzuty, a także opis całego złożonego kontekstu relacji Jasienica-Piasecki, mający swój początek w wileńskiej operacji „Ostra Brama”, są zbyt obszerne i odbiegają od głównej myśli niniejszego tekstu ${ }^{124}$. Niech jako odpowiedź - na zasadzie pars pro toto — posłuży notatka sporządzona przez pracowników MSW na początku lat 60., którzy byli zainteresowani pozyskaniem Jasienicy dla swoich celów:

Po aresztowaniu, w/w zainteresował się Bolesław Piasecki, który wykorzystując swoje kontakty z MBP spowodował, po uprzednim przeprowadzeniu kilku rozmów z P. Jasienicą $\mathrm{w}$ więzieniu, uwolnienie go $\mathrm{z}$ aresztu i umorzenie śledztwa. W rezultacie Jasienica został zwolniony z więzienia 16 maja 1949 [sic!] i od tego czasu do 1956 r. współpracował z PAX-em jako publicysta, będąc zatrudnionym w „Tygodniku Powszechnym”, nad którym wówczas PAX miał swój patronat. Należy stwierdzić, że Piasecki doceniając wówczas pozycję Jasienicy w środowiskach katolickich oraz jego związki z hierarchią liczył się z tym, że uda się PAX-owi pozyskać w/w do organizacyjnej współpracy. Jednakże Jasienica, podobnie jak Turowicz i niektórzy inni redaktorzy „TP”, poza luźną współpracą publicystyczną i sporadycznymi kontaktami z kierowniczymi działaczami PAX-u, nie wyraził zgody na formalne przystąpienie do PAX-u. W 1956, przed październikiem, Jasienica zerwał współpracę publicystyczną i kontakty z PAX-em. Jasienica był przeciwnikiem ideologicznym PAX-u, a swoją ówczesną współpracę traktował jako zło konieczne. Po październiku nie wiązał się organizacyjnie z żadną z działających grup katolickich, chociaż zawsze darzył sympatią środowisko „TP”. Świadczą o tym aktualne spotkania i rozmowy ze Stommą i Turowiczem, wygłoszone odczyty w Klubie Inteligencji Katolickiej w W-wie i Krakowie itp. ${ }^{125}$

Zarzut kolejny dotyczył działalności Jasienicy w Rozgłośni „Kraj”. Żeby zrozu-

${ }^{122}$ Znowu cyfry (1947 nr 4, s. 2); Walory pracy nauczycielskiej (1946 nr 23, s. 4); Problem $n r 1$ (1946 nr 44, s. 2).

123 J. Mackiewicz, Casus Pawet Jasienica, s. 2.

${ }^{124}$ Więcej na ten temat w powstającej pracy: A. Kierys, „Paweł Jasienica. Biografia publicysty w PRL-u".

125 IPN BU, 0204/19/1, „Uzupełnienie do informacji w sprawie Pawła Jasienicy”, k. 103-104. Powyższa notatka bez podpisu i datacji opatrzona jest odręcznym dopiskiem, z którego wynika, że sporządził ją Borowski w 1961 roku. Ustaleń takich dokonał towarzysz Wawrzyniewicz, a potwierdził Chlebicki, 27 października 1964 roku (również adnotacja odręczna na dokumencie). 
mieć motywy postępowania wielu polskich intelektualistów w połowie lat 50., w tym Jasienicy, należy wziąć pod uwagę ówczesne nadzieje społeczeństwa polskiego na poprawę sytuacji w Bloku Wschodnim po śmierci Stalina i związane z tym oczekiwanie normalizacji stosunków społeczno-politycznych.

Jasienica — czego nigdy nie ukrywał — żył rzeczywistą nadzieją na popaździernikową odwilż, na powstanie państwa ze wszech miar „,normalnego” — z socjalistycznym co prawda ustrojem, ale demokratycznym społeczeństwem — bez cenzury, indoktrynacji i bezpieki. Nowy kraj miał być domem dla powracającej emigracji, która wcześniej obawiała się aresztowań, inwigilacji i dyskryminacji. Teraz mogła zasilić ciągle jeszcze uszczuplony po wojnie naród, szczególnie w kręgach inteligenckich gdzie straty wojenne były duże i dla odradzającego się społeczeństwa szczególnie dotkliwe. Już w 1949 roku pisał, że na rzeczywiste życie w kraju wpływ mają jedynie ci Polacy, którzy w nim mieszkają — nie zaś emigracja:

Losy Polski zależą wprawdzie od tego, co się dzieje na szerokim świecie, ale masa Polaków kształtować może historię ojczystą działając tutaj, na nadwiślańskich piaskach, a nie tam, ,gdzie cytryna dojrzewa" ${ }^{, 26}$.

W 1955 roku wraz z czterdziestoma ośmioma intelektualistami podpisał apel o powrót emigracji do kraju:

Zwracamy się do was jako do tych, którzy byli wśród nas, których z nami łączyła wspólna walka $\mathrm{z}$ hitlerowskim wrogiem i wspólne nieraz poglądy. Zwracamy się do was jako ludzie, którzy teraz tu tworzą nową Polskę i pragną widzieć was przy tej pracy ${ }^{127}$.

Wśród sygnatariuszy obok Jasienicy byli: Maria Dąbrowska, Zofia Starowieyska-Morstinowa, Antoni Słonimski, Julian Przyboś, Karol Estreicher, Jerzy Zawieyski, Aleksander Ford, Kazimierz Kumaniecki i ks. Józef Iwanicki — rektor KUL-u. „Apel 48" ogłoszony był w ramach większej akcji normalizowania stosunków kraju z Polonią, poprawienia wizerunku PRL po kompromitujących ją audycjach Światły ${ }^{128}$ i udowodnienia, że w Polsce nastąpiła rzeczywista liberalizacja życia politycznego i kulturalnego, a nawet zainicjowanie masowego powrotu emigracji do kraju ${ }^{129}$. Celowi temu służyć miało specjalne Towarzystwo Łączności z Wychodźstwem „Polonia” oraz Rozgłośnia „Kraj”, na antenie której wypowiadał się i Jasienica — tradycyjnie obok takich tuzów jak: Kazimiera Iłłakowiczówna, Maria Dąbrowska, Antoni Słonimski, Aleksander Kamiński, Jan Rzepecki. Najważniejsze audycje drukowane były dodatkowo w „Biuletynie Rozgłośni «Kraj»”, czyli pisemnej formie najważniejszych audycji ${ }^{130}$.

Jasienica umieścił tam trzy artykuły: Wieże Krakowa, Dziwna polskość i Skarby wawelskie. Pierwszy dotyczył polemiki z Janem Bielatowiczem na temat sum łożonych

${ }^{126}$ P. Jasienica, Dziesięciolecie, Tygodnik Powszechny 1949 nr 35, s. 5.

${ }^{127}$ Rodacy za granicą!, Biuletyn Rozgłośni „Kraj” 1955 nr 1, s. 1-2; M. Fik, Kultura polska po Jatcie, s. 217; S. Cenckiewicz, Udziat aparatu bezpieczeństwa PRL $w$ drugiej kampanii reemigracyjnej (1955-1957), [w:] Aparat bezpieczeństwa wobec emigracji politycznej $i$ Polonii, pod red. R. Terleckiego, Warszawa 2005, s. 257-267.

${ }^{128}$ W 1953 roku zbiegł na Zachód (przez Berlin Zachodni) wysoki funkcjonariusz Ministerstwa Bezpieczeństwa Publicznego, płk Józef Światło. Jako wicedyrektor Departamentu X miał dostęp do najbardziej strzeżonych tajemnic władz partyjnych i rządowych. Od 1954 roku zaczęto nadawać audycje Światły w rozgłośni Radia Wolna Europa ujawniające kulisy sprawowania władzy przez reżim komunistyczny.

${ }_{129}$ A. L. Sowa, Historia polityczna Polski 1944-1991, Kraków 2011, s. 200-201.

${ }^{130}$ A. Friszke, Życie polityczne emigracji, Warszawa 1999, s. 235. 
przez państwo na konserwację zabytków w Polsce ${ }^{131}$. Drugi był skróconą wersją artykułu Moralne zwłoki szlachcica kresowego dotyczącego powieści Józefa Mackiewicza Droga doniką ${ }^{132}$. Trzeci tekst był swoistym apelem do wpływowych kół emigracyjnych, by poparły akcję sprowadzenia do Polski skarbów wawelskich przechowywanych w Kanadzie ${ }^{133}$.

Główne szańce emigracji — „Wiadomości” londyńskie i „Kultura” paryska — od początku negatywnie odniosły się do inicjatywy władz i krajowych intelektualistów; działania te nazywano nawet „ostatnim propagandowym szańcem stalinizmu”134. Mimo to około trzech tysięcy Polaków wróciło do kraju, a najbardziej spektakularny powrót dotyczył byłego premiera rządu na uchodźstwie, Stanisława Cata-Mackiewicza brata Józefa - który swoją decyzją sprawił osobistą i nieskrywaną radość Jasienicy ${ }^{135}$. Na rekonesans przybył także Melchior Wańkowicz, który ostatecznie zawitał na stałe w 1958 roku.

$\mathrm{Na}$ „Apel 48” redakcja „Kultury” odpowiedziała zaproszeniami dla sygnatariuszy do Maisons-Laffitte „,na przyjacielską rozmowę”, dziękując zarazem za przerwanie wieloletniego milczenia; zaproszenia imienne skierowano na adres redakcji „Tygodnika Powszechnego", do adresatów jednak nigdy nie dotarły ${ }^{136}$.

Jeśli inspiracja i działania Rozgłośni „Kraj” i całej akcji reemigracyjnej wychodziły z biura Komitetu do Spraw Bezpieczeństwa Publicznego, to mimo wszystko wywarły one niezamierzony przez władze, ale ostatecznie pozytywny wpływ na wzajemne relacje Polaków z obu stron żelaznej kurtyny. Także sprowadzenie osób o znanych nazwiskach, przyniosło reżimowi jedynie krótkotrwały sukces propagandowy, gdyż później sprawiły one wiele kłopotów kontestując, a nawet stojąc w opozycji do władzy ludowej ${ }^{137}$. Poza tym wzmocnili środowisko rodzimych intelektualistów, dając im drugi oddech.

Reasumując powyższe wywody, można śmiało założyć, że Józef Mackiewicz wykluczał możliwość swobodnego wyrażania własnych opinii u ludzi mieszkających w państwie indoktrynowanym ideologicznie, a Jasienica ewidentnie w takim państwie żył; wszystko więc co napisał było eo ipso częścią propagandy komunistycznej. Tak mogą myśleć tylko ludzie, którzy, albo nie znają pisarstwa Pawła Jasienicy — także tego z najwcześniejszego okresu lat 1946-1948, albo nie żyli w Polskiej Rzeczpospolitej Ludowej.

„Pisarz polski w kraju”, z talentem czy bez, jest de facto pracownikiem komunistycznej polityki kulturalnej, albo przestaje być pisarzem. Gdyż w każdej chwili może być zwolniony z pracy literackiej, jak każdy pracownik nie odpowiadający wymogom pracodawcy

— pisał Mackiewicz ${ }^{138}$.

${ }^{131}$ P. Jasienica, Wieże Krakowa, Biuletyn Rozgłośni „Kraj” 1955 nr 3, s. 5-6.

132 Tenże, Dziwna polskość, Biuletyn Rozgłośni „Kraj” 1955 nr 4, s. 5.

${ }^{133}$ Tenże, Skarby wawelskie, Biuletyn Rozgłośni „Kraj” 1956 nr 1, s. 8.

${ }^{134}$ Cyt. za: M. Fik, Kultura polska po Jatcie, s. 217.

${ }^{135}$ Relacja Ewy Beynar-Czeczott, Warszawa, 5 marca 2012 (w zbiorach autora).

${ }^{136}$ Redakcja „Kultury”, Do czterdziestu ośmiu, Kultura 1955 nr 11(97), s. 3-4.

${ }^{137}$ Stanisław Cat-Mackiewicz mieszkając w kraju pisał artykuły do paryskiej „Kultury” pod pseudonimem Gaston de Cerizay; wraz z Melchiorem Wańkowiczem (i Jasienicą) podpisali „List 34”. Obu reemigrantom wytoczono także procesy sądowe w PRL.

${ }^{138}$ J. Mackiewicz, Casus Pawet Jasienica, s. 2. 
Gdyby więc przyjąć założenie Mackiewicza, iż każdy obywatel PRL-u — od poety po hydraulika - jest przez swoje obywatelstwo (i na mocy tego faktu) współpracownikiem systemu, bo pracuje na jego rzecz — społeczeństwo polskie lat 1945-1989 porównać by można do pacjentów szpitala psychiatrycznego, w którym każdy obar-

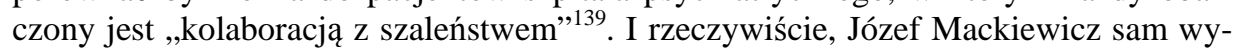
tyczał ramy „normalności” literatury polskiej, określając, kto na miano pisarza polskiego zasługuje, a kto nie. W 1967 roku napisał list otwarty do Jadwigi Czachowskiej w odpowiedzi na przesłaną mu ankietę redakcji Stownika pisarzy polskich rozesłaną do pisarzy emigracyjnych. Czytamy tam:

Droga Pani [...] jestem osobiście jedynym bodaj wyjątkiem, który nie uważa literatury PRL-u w jej całości za literaturę, i w tradycyjnym, i w ścisłym znaczeniu: polską. [...] Nie tylko komunista, ale i nie-komunista, piszący w państwach komunistycznych, tzn. podlegający i fizycznej, i psychicznej reglamentacji, ustanowionej przez ustrój komunistyczny, nie należy już do literatury swego kraju, lecz literatury typu temu krajowi narzuconego $^{140}$.

Jasienica znał środowisko jednych i drugich, to znaczy, emigracji i rodzimych komunistów. Jednym i drugim odpowiadał ostro i jednoznacznie, że nauki historii nie można traktować instrumentalnie, jako narzędzia w walce politycznej. Historia ,to nie dziwka, którą można wynająć na rogu ulicy i skłonić do wszelkich łamańców. Kto naukę historii chce traktować jak dziwkę, ten sobie samemu wystawia bardzo wymowne świadectwo" - przypominamy — pisał to Jasienica w 1956 roku, także w odpowiedzi Józefowi Mackiewiczowi ${ }^{141}$. Artykuł, w którym znajduje się cytowane zdanie i w którym wraca temat krytyki osoby Piłsudskiego dokonanej przez Mackiewicza, nie znalazł uznania u jego obrońców, a przecież ewidentnie skierowany był do autora Drogi donikąd. Mimo że artykuł ten przedrukowany był już w zbiorze Ślady potyczek, większe fragmenty przypominam raz jeszcze:

Śledzenie różnic zachodzących pomiędzy krajem i całym naszym blokiem a emigracją to nudne zajęcie. Zbyt łatwo w tej dziedzinie o odkrycia. O ileż ciekawiej szukać podobieństw, nawet w sprawach niezbyt chwalebnych.

Kraj nasz nie obfitował w zwolenników nadziewania historii coraz to innym farszem politycznym, wolał widzieć i czytać szczerą prawdę. A jednak proceder taki uprawiano, i to na bardzo wielką skalę. Świadczy o tym chociażby fakt potępienia go teraz $\mathrm{z}$ arcywysokich trybun. Zanika koniunktura na dziejopisarzy tworzących teorie, które małe dziecko jednym palcem przewróci. [Jasienica nawiązuje do zmian w polskiej historiografii na fali „odwilży” — AK].

Stało się wiele złego. Mądre przysłowie powiada, że tego, co raz napisano i wydrukowano, nawet siekierą nie można wyrąbać. Nie tak łatwo wykarczować fałsze z głów młodzieży, co poszła na politechnikę czy medycynę, wszelki kontakt z nauką historii utraciła, ale mechanicznie pamięta, czego ją uczono w szkole. Nie łudźmy się też, że bez oporu ustąpią z placu amatorzy politycznej i pisarskiej łatwizny. Przecież to bardzo wygodna metoda: autor zabiera się do „studiów”, z góry doskonale wiedząc, do jakich „wyników naukowych” dojdzie.

${ }^{139}$ I. Glatzel, Z notatek pacjenta szpitala dla umystowo chorych, czyli „Żywa śmierć” Ewy Lipskiej, [w:] Światy przedstawione. Prace z historii i teorii literatury ofiarowane Profesorowi Jerzemu Speinie, red. M. Kalinowska, E. Owczarz, J. Skuczyński, M. Wołk, Toruń 2006, s. 405-409.

${ }^{140}$ Cyt. za: M. Fik, Kultura polska po Jałcie, s. 398.

${ }^{141}$ P. Jasienica, Dziwne zbieżności, Przegląd Kulturalny 1956 nr 24; przedruk w: tenże, Ślady potyczek, s. 223. 
Trzeba będzie walczyć o pełny powrót do dobrych obyczajów naukowych. W kraju akcja ta już się rozpoczęła. Na emigracji trwają jednak stare porządki.

14 maja 1956 roku „Wiadomości” londyńskie wydrukowały rzecz, która jak najbardziej się różniąc barwą polityczną od niesławnych wystąpień niektórych „badaczy” krajowych, stosuje - o dziwo! - niezwykle podobną metodę zgłębiania historii. Jest to artykuł Józefa Mackiewicza Nasza strona medalu. kiego.

Artykuł głosi, że Józef Piłsudski był świadomym dobroczyńcą Związku Radziec-

Piłsudski — zdaniem Józefa Mackiewicza — ,ulegając koniunkturalnemu egoizmowi narodowemu", walnie, może nawet decydująco, przyczynił się do zwycięstwa rewolucji bolszewickiej w Rosji. A więc polska emigracja polityczna nie ma moralnego prawa potępiać Brytyjczyków za przyjmowanie w Londynie radzieckich mężów stanu.

Taki aktualny morał wynika z artykułu Józefa Mackiewicza. Morał — jeśli wolno się tak wyrazić - historiozoficzny sięga dalej, aczkolwiek nie został wyraźnie sformułowany: podczas drugiej wojny światowej Polacy powinni byli iść z Niemcami.

Przyzwyczailiśmy się do rozmaitych krajowych koszałków-opałków, które nas tylko nudzą. Rzut oka na emigracyjne wygibasy może jednak dostarczyć godziwej rozrywki oraz służyć ku nauce i przestrodze.

Józef Mackiewicz cytuje rozmaite książki i broszury. Głównym autorytetem jest dlań jednak znany całemu światu historyk, generał Denikin, autor wiekopomnego dzieła Kto spas sowietskuju włast' ot gibieli?, wydanego w Paryżu w roku 1937. Okazuje się, że owym spasitielem — czyli zbawicielem bolszewików — był niejaki Josif Josifowicz Piłsudskij.

Cóż czynił ten moralny wasal czerwonego Kremla? Jesienią 1919 roku zabronił podległym sobie polskim siłom zbrojnym uderzyć na położoną na Białorusi wielką stolicę Mozyrz, czego się domagał Denikin, a co niewątpliwie spowodowałoby ogólną klęskę bolszewików. Skoro zaś Polacy nie zdobyli Mozyrza: „Położenie Rosji Sowieckiej... poprawiło się znakomicie. Judenicz został rozgromiony, Denikin również, Kołczak został odparty daleko na wschód...”. Wszystko oczywiście t y lk o dlatego, że Piłsudski zamiast uderzyć na Mozyrz, jak mu to nakazywał obowiązek wobec ludzkości, wdał się z bolszewikami w pertraktacje w Mikaszewiczach, rozpoczęte we wrześniu 1919 roku. Jakeśmy widzieli, nie trzeba było długo czekać na złowrogie skutki. Klęski sypały się jednak dalej. [...]

Jednej tylko rzeczy nie możemy się jakoś dowiedzieć od Józefa Mackiewicza, historyka. Tego mianowicie, jakie siły polskie miały, uderzywszy na Mozyrz, wywrzeć wpływ na położenie wojskowe nad Morzem Białym i Czarnym tudzież nad Oceanem Spokojnym, a przez to samo na polityczną sytuację świata. Ile tego było? Dywizja? Dwie? Trzy? A może całych pięć? Bo wiadomo skądinąd, że na wiosnę 1920 roku Piłsudski wyprawił się na Kijów z siłami w stosunku do swych zamiarów wprost śmiesznymi. $[\ldots]$

Do pertraktacji z Denikinem Piłsudski wysłał generała Karnickiego. Dawniej uważałem to za pomylony pomysł, bo Karnicki był poprzednio carskim oficerem, co spowodowało upokarzające dla Polski zdarzenie. Przy pierwszym spotkaniu Denikin, który nie był człowiekiem przyjemnym, warknął: „Ja tu nie widzę żadnego generała Karnickiego, widzę pułkownika Karnickiego". Zmieniłem zdanie, przeczytawszy wydany na Zachodzie pamiętnik Józefa Becka Le dernier rapport. Beck pisze, że Piłsudski umyślnie wybrał Karnickiego, który świetnie mówił po rosyjsku i miał pełno znajomych w Denikinowskim sztabie. Dzięki temu mógł zebrać wiadomości, które pozwoliły mu dojść do wniosku, że Denikin na pewno przegra $\mathrm{z}$ bolszewikami. Piłsudski otrzymał o tym raport, i to właśnie wpłynęło na jego powściągliwość w zadawaniu się z bankrutami.

Nie tylko generał Karnicki był wtedy pewien klęski Denikina i spółki. Biali generałowie w niezawodny sposób nastrajali przeciwko sobie ludność zdobytych obszarów. $[\ldots]$

To, co Józef Beck pisze o generale Karnickim i jego misji, zdaje się wyglądać poważnie i rzeczowo. Zwłaszcza że wszystko to można podeprzeć dowodem logicznym. 
Piłsudski żywił daleko posunięte plany w stosunku do Ukrainy. Zwycięstwo Denikina i całego białego frontu musiałoby te plany po prostu przekreślić. Carska Rosja w ogóle nie uznawała istnienia narodowości ukraińskiej. Na wojnę z carską Rosją Zachód nie dałby Polsce ani jednego naboju. W roku 1918 Niemcy mianowali ,,hetmanem ukraińskim" Skoropadskiego, byłego oficera gwardii. Razu pewnego ktoś zwrócił „hetmanowi" uwage, że nie wypada przed frontem ustrojonych w żupany i szarawary „,hajdamaków” komenderować po rosyjsku. „My zdieś jeszczo, stawa Bogu, gawarim po cziełowieczieski" — odrzekł Skoropadski.

Sojusz z Denikinem oznaczałby dla Piłsudskiego konieczność wyrzeczenia się planów ukraińskich. Można przypuszczać, że dlatego także - jeśli nie przede wszystkim - nie doszło do wyprawy na Mozyrz. Chęć dopomożenia czerwonym w ich walce $\mathrm{z}$ białymi na pewno nie grała roli.

Naprawdę nie przypuszczałem, że przyjdzie mi czytać wywody pasujące Józefa Piłsudskiego na głównego dobroczyńcę Kremla. Gdybyż jeszcze spisano tę bajeczkę po hiszpańsku i wydano w Patagonii. Nie! Józef Mackiewicz używa języka polskiego.

Związek Radziecki miał wielu zawziętych wrogów. Wystrzegając się przesady jak ognia, wolno chyba jednak ryzykować tezę, że z nich wszystkich jeden Piłsudski zdobył się na pomysł zasługujący na miano politycznego. Chciał przecież oderwać Ukrainę, Białoruś i kraje bałtyckie od wszelkiego związku z Rosją i sfederować je z Polską. $\mathrm{O}$ ile wiadomo, plany jego sięgały nawet Kaukazu. I oto pan Józef Mackiewicz bierze w dłoń pióro i okiem nie mrugnąwszy, czyni z Piłsudskiego opatrznościowego męża rewolucji radzieckiej. A wszystko dlatego, że te ,prawdy dziejowe” szanowany autor uważa za wygodne pod względem politycznym.

Józef Mackiewicz — jak już kiedy indziej pisałem — woli, żeby narodu polskiego „wcale nie było, niż żeby był narodem bolszewickim i stał się instrumentem do rozpowszechniania zła na świecie".

Aby zachęcić naród do wskazanej przed chwilą ofiarności, należy mu wyttumaczyć, że już w roku 1919 zdradził swój obowiązek „antybolszewickiego przedmurza” i że podczas ostatniej wojny działał na szkodę ludzkości, pomagając Sowietom w walce z Hitlerem. A stąd już prosta droga do wniosku, że należy naprawić, co się jeszcze da, i co rychlej stawać w jednym szeregu z Niemcami Zachodnimi.

Józef Mackiewicz przemawia na emigracji raz tonem Piotra Skargi, to znów królewny Kasandry. Obyczaje „historyków”, którzy ogłaszali starych bolszewików za zdrajców komunizmu, na pewno budzą w nim grozę. No dobrze. Ale czymże innym on sam w gruncie rzeczy się zajmuje, jeśli nie kłamstwem z premedytacją?

Niektóre zbieżności i podobieństwa naprawdę zasługują na uwagę ${ }^{142}$.

W 1947 roku, kiedy na polskich uniwersytetach socjalistyczna młodzież denuncjowała swoich profesorów, a komunistyczni publicyści obrzucali inwektywami swoich nieprawomyślnych kolegów, Paweł Jasienica napisał artykuł „Życzliwość”, a w nim na końcu umieścił prosty apel:

Czy nie czas jąć się przypominania, że każdy człowiek — nawet przeciwnik polityczny — zasługuje na szacunek? I że człowieka moralnie dyskwalifikują niezgodne z etyką lub prawem czyny, a nie odmienne od innych poglądy? ${ }^{143}$

\footnotetext{
${ }^{142}$ Tamże, s. 221-226.

${ }^{143}$ Tenże, „Życzliwość”, Tygodnik Powszechny 1947 nr 26, s. 2.
} 


\section{PAWEŁ JASIENICA VERSUS JÓZEF MACKIEWICZ. WHOSE ROAD TO NOWHERE?}

Paweł Jasienica and Józef Mackiewicz shaped their world outlook in the interwar period in the administrative unit of the Second Polish Republic with its capital in Vilnius. The biggest assets of those terrains were its multi-national, multi-cultural and multi-religious tradition of the Great Duchy of Lithuania. They parted ways along with the beginning of World War II and the choices they made. Jasienica joined the Home Army, Mackiewicz-a zealous anti-communist-began his temporary cooperation with a German periodic publishing anti-Bolshevik content. And it was then where their polemics began. Jasienica replied Mackiewicz in underground press, that every invader-be it Western or Eastern-is as dangerous, and his goal is to destroy us. The Home Army sentenced Józef Mackiewicz to death for collaborating with the Nazi occupying unitsthe sentence was never carried out.

KEY WORDS: Paweł Jasienica; Józef Mackiewicz; Vilnius; People’s Republic of Poland. 